\title{
CORPORATE TRANSACTIONS AFTER ERISA: ACQUISITIONS, REORGANIZATIONS AND DIVESTITURES
}

\author{
HERBERT W. KRUEGER, JR.*
}

I. IntRodUCtION................................. 491

II. Single Plan/Multiple Plan Issue.................. 493

III. LIABILITY UNDER TITLE IV OF ERISA ............. 495

A. What Constitutes a Plan Termination.............. 496

B. Benefits Guaranteed on Plan Termination ........... 497

C. Amount of Liability on Termination .............. 497

D. Liability Other than upon Termination of a Plan .... 498

1. Generally ................................ 498

2. Withdrawal ............................. 499

3. Cessation of Operations at a Facility ........... 500

E. Lien for Liability ............................ 501

F. Liability of Controlled Group .................... 501

G. Liability of Successor Corporations............... 502

H. Liability of Transferor Corporations ............. 502

IV. Minimum Participation Standards .............. 504

A. Service with a Predecessor Employer ............. 504

B. Coverage Tests................................ 505

V. Additional Vesting .......................... 506

A. Termination, Partial Termination or Discontinuance of

Contributions ................................. 507

1. General .................................. 507

2. Continuation of Plans ..................... 508

3. Plan Merger ............................ 509

(a) Type of plans ...................... 509

(b) Curtailment of eligibility, benefits or vesting. 510

4. Replacement of Plans ...................... 512

Copyright $\odot 1979$ by Herbert W. Krueger, Jr.

* B.A., 1970, University of Wisconsin; J.D., 1974, University of Chicago; Associate, Mayer, Brown \& Platt, Chicago, Illinois.

THE FOLLOWING CITATIONS WILL BE USED IN THIS ARTICLE:

Employee Retirement Income Security Act of 1974, Pub. L. No. 93-406, 88 Stat. 829 (codified in scattered sections of $5,18,29,31,42$ U.S.C.) [hereinafter cited by session law sections of ERISA];

Opinion Letters of Pension Benefit Guaranty Corporation [hereinafter cited as PBGC Opinion Letters]. 
5. Discontinuance of Accruals Under a Defined Benefit Plan .......................... 512

6. Discontinuance of Contributions Under a Defined Contribution Plan........................ 514

7. Time of Termination or Discontinuance and Af-

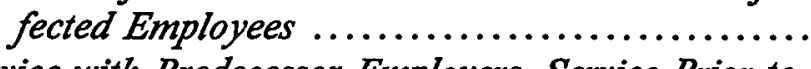

B. Service with Predecessor Employers, Service Prior to the Establishment of a Plan and Changes in Vesting Schedules.................................... 516

1. General ............................... 516

2. Predecessor Employers .................. 516

3. Periods During Which a Plan Is Not Maintained. 517

4. Changes in Vesting Schedules ............... 518

VI. Funding AND DEdUCTIBILITY OF CoNTRIBUtions ..... 518

A. Minimum Funding Standards................ 518

B. Deductibility of Contributions .................. 520

1. Deductibility of Contributions Generally........ 520

(a) Ordinary and necessary expenses ......... 520

(b) Pension and annuity plans............. 521

(c) Stock bonus and profit sharing plans....... 522

(d) Overlapping plans .................. 522

2. Section 381 Transactions .................. 523

(a) Applicability ..................... 523

(b) Contribution carryforward and deduction carryovers ........................ 524

(c) Application of section $404(a)(6)$ to contributions by acquiring corporation ........... 524

(d) Contributions attributable to past-service benefits .......................... 525

3. Non-Section 381 Transactions .............. 525

(a) Generally ....................... 525

(b) Transferor corporation .............. 525

(c) Acquiring corporation ................ 527

VII. REPORTING AND DISCLOSURE REQUIREMENTS ......... 529

A. Reports To Be Filed with the IRS ............. 529

1. Annual Return ........................ 529

2. Annual Registration Statement ............. 530

3. Change in Status .................... 530

4. Valuation Statement on Plan Merger or Transfer of Assets or Liabilities ..................... 530

5. Change in Plan Years................... 530

6. Application for Determination Letter ......... 531 
B. Reports To Be Filed with the Department of Labor .. 531

1. Annual Report ......................... 531

2. Description of Plan and Material Modifications .. 531

3. Terminal and Supplementary Reports......... 531

C. Reports To Be Filed with the PBGC............. 531

1. Annual Reports ......................... 532

2. Notice of Plan Termination ................. 532

3. Notice of Reportable Events ............... 532

4. Notice of Facility Shutdown or Withdrawal by Substantial Employer ....................... 532

D. Disclosures to Participants ................. 533

1. Description of Material Modification of Plan .... 533

2. Statement of Deferred Vested Benefits.......... 533

VIII. Miscellaneous Considerations .................. 533

A. Review of Documents and Funding .............. 533

B. Prohibited Transaction Potential ................. 534

C. Section 415 Problems ......................... 535

1. Limitation Year ......................... 535

2. Years of Service for Defined Benefit Plan Limitation..................................... 535

3. Years of Service for Defined Contribution Fraction ...................................... 536

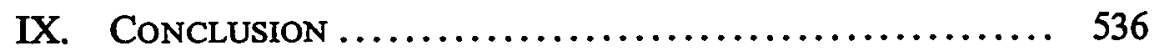

\section{INTRODUCTION}

A recent Wall Street Journal headline read, "Steel Industry's Unfunded Pension Liabilities Seen Deterring Closings of Inefficient Plants." In that article one analyst concluded that the domestic steel industry is "held captive by its unfunded pension liabilities"2 and that the industry's hopes for greater efficiency via the closedown of its least profitable plants may be unreahistic because of those liabilities. This analyst concluded, partially on the basis of the 1977 plant closings at Bethlehem Steel, in which Bethlehein set up a $\$ 375$ million special reserve for unfunded future pension liabilities for 12,000 laid-off employees, ${ }^{3}$ that the industry could not stand the drastic alteration of its capital structure that would result from the necessary write-offs that

1. Elia, Steel Industry's Unfunded Pension Liability Seen Deterring Closings of Inefficient Plants, Wall St. J., Apr. 25, 1978, at 47, col. 3.

2. Id.

3. Id. Under this reserve fund each employee's future pension liability was $\$ 31,250$, as compared to the previously reported unfunded vested liability of $\$ 10,933$ and unfunded priorservice liability of $\$ 9,862$. 
would follow large-scale closedowns. ${ }^{4}$

Other articles appearing in periodicals such as Fortune Magazine, Business Week and U.S. News and World Report have stressed coinparisons between the net worth and the pension habilities of inajor U.S. corporations. Such articles evidence a growing awareness that employee benefit plans, particularly defined benefit pension plans, ${ }^{5}$ inay have a significant impact on the economic health of a corporation, and that the impact may not be entirely reflected in the corporation's financial statements. Unfortunately, many corporate acquisitions, divestitures and reorganizations are still concluded without prior analysis of the existing employee benefit plans, the effects which the structure of the transaction may have on those plans and the resultimg impact on the corporations.

The purpose of this Article is to review some of the effects on qualified retirement plans ${ }^{6}$ resulting from corporate inergers, acquisitions, reorganizations, divestitures and hquidations, all of which are referred to below as "Corporate Transactions." In particular, this Article deals with the liabilities that may be imposed under Title IV of ERISA; the effects that a Corporate Transaction may have on compliance with the minimuin participation standards imposed by section 410 of the Internal Revenue Code (Code); the additional vestimg in plan benefits that nay result from a Corporate Transaction; the effect that a Corporate Transaction may have on the anount of contributions required to fund plan benefits and on the deductibility of those contributions; and the reporting and disclosure requirements that may be imposed on a plan administrator as a result of a Corporate Transaction.

This Article does not deal with the requirements imposed by scctions 401(a)(12) and 414(1) of the Code and section 208 of ERISA with respect to the inerger or consolidation of plans or the transfer of plan assets or liabilities. Nor does it deal with the tax consequences to employees of the various alternatives available to the parties to a Corpo-

4. $I d$.

5. Technically defined in I.R.C. $\$ 414(j)$ as any plan which is not a defined contribution plan, a defined benefit plan generally promises a participant a specified benefit at retirement, for example, $x$ anount per year of service or $x$ percent of final pay. A collectively bargained plan which promises a specified benefit on retirement is a defined benefit plan even though the collective bargaining agreement requires only a specified contribution by the employer, for example, ten cents per hour. Connolly v. PBGC, 581 F.2d 729 (9th Cir. 1978), cert. denied, 99 S. Ct. 1278 (1979).

6. A qualified retirement plan is a pension, profit sharing or stock bonus plan qualified under $\$ 401$ of the Code. Unless otherwise indicated, wherever the term "plan" or "plans" is used in this Article, it refers to a qualified retirement plan or plans. 
rate Transaction.

\section{Single Plan/Multiple Plan Issue}

In many situations, the effects of a Corporate Transaction on a qualified plan cannot be determined until it is known whether the plan will be treated under the Code and ERISA as a single plan. This issue typically arises with respect to a plan maintained by a group of employers (whether or not all or any of thein are nembers of a controlled group of corporations as described in section 414(b) of the Code), but may also arise with respect to a plan mamtamed by one einployer for various groups of employees.

Both the Department of the Treasury and the Pension Benefit Guaranty Corporation (PBGC) have proposed regulations defining a "single plan." Under the proposed regulations a plan will be a single plan if, and only if, on a going concern basis, all of the plan assets are available to pay all participants' benefits. ${ }^{7}$ Thus, the number of plan documents, the number of benefit formulae, the number and type of funding vehicles, for example, trusts, annuity contracts, or allocated insurance contracts, and the inethod of allocating contributions are all irrelevant to the determination of whether there is one plan or a number of plans. ${ }^{8}$ It is also irrelevant whether all plan assets are available for all participants' benefits in the event that the plan terminates. For example, a plan may be a simgle plan even though on termination of the plan, or on the spinoff of a portion of the plan, plan assets are allocated among groups of participants based upon the prior contributions of their employers. ${ }^{9}$

7. Proposed Treas. Reg. $\$ 1.414(1)-1(b)(1), 42$ Fed. Reg. 33,770 (1977); Proposed PBGC Reg. 29 C.F.R. \& 2617.2, 42 Fed. Reg. 59,285 (1977). While ouly the PBGC regulations contain the language "on a going concern basis," the supplementary information accompanying those regulations states that the PBGC definition is consistent with the IRS definition. It is the author's understanding that final Treasury regulations will contain the "going concern basis" language. While technically defining a single plan for $\$ 414$ purposes only, the proposed Treasury regulation is incorporated by reference in regulations proposed under $\$ 413$ and is partially imcorporated in substance in the IRS/DOL/PBGC annual return/report form 5500 .

8. Proposed Treas. Reg. § 1.414(1)-1(b)(1), 42 Fed. Reg. 33,770, 33,771 (1971); Proposed PBGC Reg. \& 2617.2, 42 Fed. Reg. 59,285, 59,286 (1977).

9. 42 Fed. Reg. $59,285,59,286$ (1977). Note, however, that any such allocation under a single plan might violate the vesting requirements of $\$ 411$ of the Code. Treas. Reg. $\$ 1.411(\mathrm{a})$ 4(a) (1977). Prior to the proposed PBGC regulations, the PBGC took the position that a plan was not a single plan if all plan assets were not available to pay all plan benefits on termination of the plan. The following PBGC Opinion Letters, some of which were issued prior to the proposed regulations, illustrate the apphication of the simgle plan definition: 78-16 (June 2, 1978); 78-15 (June 2, 1978); 76-117 (Nov. 3, 1976); 76-83 (June 16, 1976); 76-40 (Mar. 19, 1976); 76-8 (Jan. 15, 1976); 75-1 16 (Dec. 31, 1975); 75-105 (Dec. 31, 1975). See also 1RS Private Letter Ruling 7828049 1978 Fed. Taxes Private Letter Rulings (P-H) II 2232; Private Letter Ruling 7852121 (Oct. 2, 1978), 1978 Fed. Taxes Private Letter Rulings (P-H) I] 2438. 
In many cases the applicable plan document or documents are likely to be ambiguous as to whether all plan assets are available on a going concern basis to pay all participants' benefits. In such a case the annual report filed with the Internal Revenue Service (IRS) may contain information that will indicate whether all plan assets are intended to be so available. Under section 412 of the Code, a funding standard account must be established with respect to eacli pension plan. Each annual report filed with the IRS with respect to a pension plan must include a Schedule B evidencing comphance with section 412. Accordingly, if a plan is in reahty a number of plans, a separate fundimg standard account inust be established and a separate Schedule B filed with respect to each plan. On the other hand, if the plan is merely a simgle plan to which, for example, each member of a controlled group contributes, only a single funding standard account is to be established. ${ }^{10}$

While the single plan/multiple plan issue may be important in Corporate Transactions involving plans mamtained by unrelated corporations and plans maintained by a single corporation for various groups of employees, the issue will most commonly arise in Corporate Transactions involving plans maintained by a controlled group of corporations. For example, if one member of a controlled group of corporations is acquired by outside interests and therefore withdraws from a defined benefit pension program maintamed for the benefit of all the employees of that group, the withdrawal may be treated either as a termination of an individual plan maimtamed by the acquired member, or as a partial termination of a single plan maintaimed by the entire controlled group. For reasons discussed below, the consequences of these alternative treatments differ significantly.

If the controlled group's pension program is treated as a number of plans (one mamtamed by each member) and the acquired member terminates its plan, then first, the acquired member's employees will becoine fully vested in their accrued benefits to the extent funded; second, the PBGC will guarantee certain benefits under the plan; and finally, the acquired member will become hable under Title IV of ERISA for the amount by which the value of the guaranteed benefits exceeds the available plan assets. Other members of the controlled group of which the acquired corporation is a nember on the date its plan is

10. I.R.C. $\$ \S 412(\mathrm{~b})(1), 414(\mathrm{~b})$. Other evidence of whether all assets are intended to be available on a going concern basis for all benefits includes plan provisions relating to restrictions on assets during periods of delinquencies in einployer contributions, on withdrawal by an employer or on termination of the plan, actuarial valuations and IRS and Department of Labor reports including the pre-ERISA IRS form 990-P and Department of Labor form D-2. 
terminated, as well as successors to the acquired corporation, may also be liable under Title IV.

If, on the other hand, the controlled group's pension program is treated as a single plan to which all of the members contribute, and the acquired member terminates its participation in the plan, then the acquired meinber's employees will receive additional vesting in their accrued benefits only if its withdrawal is treated as a partial termination of the plan. Regardless of whether the withdrawal is treated as a partial termination, there will generally be no PBGC guarantee of plan benefits and no liability incurred by the acquired member under Title IV. The remaining controlled group members will be required under section 412 of the Code to continue to fund the vested benefits accrued by employees of the acquired member prior to its acquisition. While the reinaining controlled group members could cause the plan to be split into two plans (in accordance with section 414(1) of the Code) and then terminate the plan applicable to the former employees of the acquired meinber, the Title IV liability arising by virtue of such a plan termination would be imposed on tlie remaining controlled group members since tlie acquired member lias terminated its participation in the plan and lias ceased to be a member of the controlled group.

\section{Liability UNDER TItLe IV of ERISA}

Among the inost significant and controversial consequences of ERISA were, first, the establishment of a nonprofit corporation within the Department of Labor, known as the Pension Benefit Guaranty Corporation (PBGC), to guarantee the payment of basic benefits upon the termination of a defined benefit pension plan and, second, the imposition of liability on contributing employers for the amount by whicli the value of the guaranteed benefits exceeds the value of plan assets allocable to those benefits.

The benefit guarantee and employer liability provisions are both set forth in Title IV of ERISA and, with few exceptions, ${ }^{11}$ are automatically applicable to any defined benefit pension plan, other than a "inultiemployer plan,"12 terminating on or after September $2,1974,{ }^{13}$ and to

11. ERISA $\S 4021$ (b) sets forth limited exceptions to coverage.

12. The term "multiemployer plan" denotes a collectively bargained plan to which more than one employer contributes but to which no one employer or controlled group contributes $50 \%$ or more of the aggregate contributions in any year ( $75 \%$ for years after the $50 \%$ test has once been met), and under which benefits attributable to service with an employer during the period for which that employer contributes to the plan will be payable under the plan even if the employer ceases making contributions. ERISA § 4001(a)(3) (1.R.C. § 414(f)). If a defined benefit pension plan which terminates on or after September 2, 1974, but before July 1, 1979, does not ineet the preceding definition of a multiemployer plan, Title IV will automatically apply notwithstanding the fact that more than one employer may contribute to the plan.

13. ERISA § 4082(a). 
any defined benefit "multiemployer plan" terminating on or after July $1,1979 .{ }^{14}$ In addition, the PBGC has discretion in limited circumstances to guarantee benefits and impose liability with respect to defined benefit multiemployer plans terminating on or after September 2, 1974, but before July $1,1979 .{ }^{15}$

Title IV does not apply to defined contribution plans, that is, money purchase pension plans, profit sharing plans, stock bonus plans and employee stock ownership plans. ${ }^{16}$ While the discussion below deals only with the current structure for guaranteemg benefits and imposing employer liability, it should be noted that on July 1, 1978, the PBGC submitted two reports to Congress suggesting that substantial alterations in the existimg structure may be necessary. ${ }^{17}$ Included among the alternatives under consideration by the PBGC is one proposal whereby an employer would be required to contmue to fund a pension plan until all vested benefits were fully funded. In such a case, benefit guarantees would become applicable only in the event of the employer's bankruptcy.

\section{A. What Constitutes a Plan Termination.}

Title IV guarantees and liability are generally triggered by the termination of a pension plan. Whether or not there has been such a termination will be readily apparent in most Corporate Transactions; lowever, four situations are wortlyy of note. First, if a pension "plan" is treated as a number of plans, what may appear to be only a withdrawal from the plan by one employer or a discontinuance of a plan as applied to one group of employees may in fact be a termination of a single plan maimtaimed by that employer or for those employees. Second, a conversion of a defined benefit pension plan into a defined contribution plan is a termination of the defined benefit plan. ${ }^{18}$ Third, a freezing of a defined benefit plan, that is, the cessation of further benefit accruals but the contmuation of plan contributions, is not a plan termination. ${ }^{19}$ Finally, if the parties to a Corporate Transaction imtend

14. ERISA § 4082(c).

15. Id.

16. Unless otherwise indicated, any reference to a "plan" within section III of this Article refers only to a defined benefit pension plan.

17. One report, entitled Multiemployer Study Required by P.L. 95-214, dealt with inultiemployer plan guarantees and liability; the other, entitled Contingent Employer Liability Insurance: Status Report to the Congress, dealt with both multiemployer plan liability and nonmultieinployer plan liability.

18. ERISA § 4041(f).

19. PBGC Opinion Letters 76-77 (June 10, 1976); 76-71 (May 26, 1976); 76-39 (Mar. 19, 
to terminate a plan, the plan document as well as other applicable documents (for example, collective bargaining agreements) must be reviewed to determine if there are any restrictions on the parties' right to do so.

The plan termination date is critical both to a determination of the amount of benefit guarantees and to a determination of the limits on employer liability. If the parties to a Corporate Transaction terminate a plan, the date of termination should be clear in most cases; note, however, that section 4048 of ERISA provides that, for purposes of Title IV, the date of termination will be the date agreed to by the PBGC and the plan administrator or, in the absence of agreement, the date established by the court. ${ }^{20}$

\section{B. Benefits Guaranteed on Plan Termination.}

If a plan is covered by Title IV on the date on which it terminates, the PBGC will, subject to certain limitations, guarantee all vested pension benefits payable under the plan. The most significant limitations are a dollar limitation on monthly benefits $(\$ 750$ adjusted proportionately to post-ERISA increases in the social security wage base) and a five-year phase-in for increases in the level of plan benefits. ${ }^{21}$

\section{Amount of Liability on Termination.}

If, at the time it is terminated, a plan is maintained by a single employer, ${ }^{22}$ section 4062(b) estabhishes the amount of employer hability as the lesser of the amount by which the current value of guaranteed benefits exceeds the current value of plan assets allocable to those benefits, both determined as of the date of termination, or thirty percent of the net worth of the einployer. ${ }^{23}$

If, at the time it is terminated, a plan is mamtamed by more than one employer, that is, if it is a simgle plan and if more than one employer inakes contributions under the plan (whether or not it is a inultiemployer plan), the liability of the employers is determined under

1976). Note, however, that if a plan is amended to provide that benefit accruals and plan contributions are discontinued, the plan will be treated by the PBGC as terminated. PBGC Opinion Letter 76-42 (Apr. 30, 1976).

20. See text accompanying notes $76-77$ infra.

21. ERISA $\S 4022(\mathrm{~b})(3)$, (8). Additional limitations are imposed by the remaining provisions of $\$ 4022$ and by 29 C.F.R. $\$ 2605.1$ (1978).

22. As discussed in the text accompanying note 39 infra, the PBGC takes the position that a controlled group of corporations is treated as if it were a single employer.

23. Net worth is determined as of any date chosen by the PBGC within the 120-day period preceding the date of plan termination on whatever basis in the PBGC's opimon best reflects the current status of the employer's operations and prospects. ERISA $\$ \$ 4062$ (b), (c). 
section 4064. Under section 4064(a), liability may be imposed on any employer who contributed to the plan within the five plan years preceding the date of termination. Under section 4064(b), the amount of each such employer's liability may be determined either by allocating the aggregate amount of unfunded guaranteed benefits among the employers pro rata according to the contributions required of them during the five plan years ending prior to the plan termination (and applying the thirty percent of net worth limitation separately to each employer), or by any other equitable basis prescribed by the PBGC in regulations. The potential liability of a corporation contributing to a multiemployer plan in a declining industry may be particularly severe. When an employer withdraws from the plan, the ongoing liability for funding its einployees' benefits is immediately shifted to the remaining employers, ${ }^{24}$ and the hability for their benefits in the event that the plan terminates is gradually shifted to the remaining employers until, after five years, the entire liability has been shifted to them. The combination of incrcased contributions to the plan and increased liability in the event of plan termination may force some of the remaining employers to withdraw from the plan, thereby creating even greater pressure on the other employers.

While the statutory language seems to apply the thirty percent of net worth limitation on a plan by plan basis, the PBGC has taken the position that when two plans are terminated simultaneously, the maximum hability will be thirty percent of an employer's net worth, not sixty percent. ${ }^{25}$

\section{Liability Other than upon Termination of a Plan.}

1. Generally. In most cases no employer liability is imposed under Title IV until a plan is terminated. ${ }^{26}$ There are two situations im

24. I.R.C. \$ 412. Note, however, that the Conference Committee report states that any difference between reasonably anticipated contributions during the term of a collective bargaining agreement and the actual amount contributed should be treated as an amortizable experience loss rather than a funding deficiency which would have to be corrected immediately. H.R. REP. No. 1280, 93d Cong., 2d Sess. 285 (1974).

25. PBGC Opinion Letter 76-62 (Apr. 30, 1976). If the limitation were applied on a plan-byplan basis, the result would, in many cases, appear to be in direct conflict with the congressional purpose in imposing the limitation. For example, if an employer or controlled group terminated a "plan" which under the proposed PBGC and IRS regulations is, in fact, a group of individual plans with identical terms, the liability could easily exceed the total net worth of the employer or controlled group.

26. For example, the PBGC does not guarantee benefits upon the partial termination of a plan, for exainple, an exclusion from the plan of a class of participants, PBGC Opinion Letter 7584 (Aug. 21, 1975), or upon the "freezing" of a plan, that is, the total cessation of benefit accruals but the continuation of plan funding. PBGC Opinion Letters 76-77 (June 10, 1977); 76-71 (May 26, 1976); 76-39 (Mar. 19, 1976). 
which an employer may incur a liability prior to the termination of a plan: first, when it withdraws from a plan to which more than one einployer contributes; second, when the cessation of operations at a facility results im a decrease of more than twenty percent im the total number of employees participating under a plan. In addition, other circumstances may cause the PBGC to institute proceedings to terminate a plan and to impose hability on the employer. ${ }^{27}$

2. Withdrawal. If a "substantial employer"28 withdraws from a plan maintaimed by more than one employer, it will mcur a liability to the PBGC unless the benefits guaranteed under Title IV are fully funded or unless there is a sufficient indemnity agreement in effect among all remaining contributing employers. ${ }^{29}$ If a Corporate Transaction takes the form of a sale of assets, the seller may be treated as withdrawing froin a plan covering the affected employees even though the buyer reemploys those employees and makes contributions to the plan on their behalf. ${ }^{30}$

Tle amount of liability imcurred by a substantial employer upon its withdrawal from a plan may be determined in two ways. Generally, liability will be determined under section 4063(b) as if the plan had terminated on the withdrawal date and the liability for unfunded guaranteed benefits were allocated among the contributing employers either proportionately according to required contributions over the preceding five years or on any other equitable basis prescribed in PBGC regulations. If the substantial employer's liability is determined under section 4063(b), it will be required either to pay the amount of the liability to the PBGC to be leeld in escrow or to furnish a bond equal to $150 \%$ of the liability. If the plan is not terminated within five years of the withdrawal, the escrowed funds will be returned without imterest, or the bond will be cancelled. If the plan is terminated within five years, the funds will be used for the benefit of the plan with any excess funds refunded to the substantial employer. ${ }^{31}$

The alternative method for determining the substantial employer's liability upon withdrawal is provided under section 4063(d). If the

27. One of the bases upon which the PBGC may institute proceedings to terminate a plan is the expectation of an unreasonable increase in the possible long-run loss to the PBGC if the plan is not terminated. ERISA \& 4042(a)(4).

28. A substantial employer is an employer (or affiliated group) which has contributed ten per cent or more of all employer contributions to the plan either during the two immediately preceding plan years or during the second and third preceding plan years. ERISA \& 4001(a)(2).

29. See text accompanying note 33 infra.

30. PBGC Opinion Letter 77-138 (Apr. 8, 1977).

31. ERISA § 4063(b). 
withdrawal results in a significant reduction in aggregate contributions, the PBGC inay equitably allocate plan assets between employees of the withdrawing employer and employees remaining in covered service under the plan. The portion allocated to employees of the withdrawing substantial einployer would be treated as a termination, and the remaining portion would be treated as a separate plan.

No liability is imposed under section 4063 when an employer other than a substantial employer withdraws from a plan to which more than one employer contributes. However, as noted above, if what appears to be a single plan is really a number of individual plans, then what appears to be a withdrawal may, instead, be a termination of one of those plans. Thus, where all plan assets are not available on a going concern basis to pay all participants' benefits, a "withdrawal" by an employer may be treated as a termination of a smgle plan by that employer. $^{32}$

Under section 4063(e), the PBGC may waive the hability otherwise imposed upon a withdrawing substantial employer whenever it deterinines that there is an indemnity agreement in effect among the other employers under the plan which is adequate to satisfy the purposes of the sections dealing with liability on termination of, or withdrawal from, a plan. An indemnity agreement need not expressly address the remaining employers' responsibility for satisfying the withdrawn employer's contimgent liability. For example, in one situation, the PBGC held that the funding obhigations agreed to by the remaining employers under the applicable collective bargaining agreements constituted an indemnity agreement which fulfilled the requirements of section 4063(e)..$^{33}$

3. Cessation of Operations at a Facility. The second situation in which an employer may mcur a liability under Title IV prior to the termination of a plan arises when the employer ceases operations at a facility and, as a result, the employment of more than twenty percent of the employees participating under any of its plans is terminated. In such a case, section 4062(e) provides that the employer is to be treated as if it were a substantial employer with respect to the plan and that the provisions of Title IV relating to liability on withdrawal from, or termination of, a plan maintained by more than one employer become applicable. $^{34}$

32. PBGC Opinion Letter 76-88 (June 25, 1976). Note, however, that the subject plan might be treated as a single plan under the proposed PBGC regulation discussed in note 7 supra.

33. PBGC Opinion Letter 78-3 (Mar. 27, 1978).

34. Section 4062(e) may apply to one or more of an einployer's plans even though the 
The freezing of a plan is not treated as a plan termination and will generally not result in either guarantees or habilities under Title IV. If, however, the freezing of the plan is in conjunction with the cessation of operations at the facility at which plan participants are employed, it appears that under section 4062(e) the PBGC may require the employer to post a bond or establish an escrow as if the einployer were a withdrawing substantial employer under section 4063 . However, the PBGC may waive any such bond or escrow requirement if the employer's agreement to continue funding the plan meets the requirements of section 4063(e).

It may be possible for an employer selling a facility to avoid the application of section 4062(e) if the buyer establishes a substantially identical plan for the affected employees or is substituted as the employer under the applicable plan. ${ }^{35}$

\section{E. Lien for Liability.}

If, after demand, an employer neglects or refuses to pay any liability incurred by it under Title IV, a lien in the amount of the hability (the lesser of the employer's share of insufficiency or thirty percent of the employer's net worth) arises in favor of the PBGC upon all property and rights to property belonging to the employer. ${ }^{36}$ Although the PBGC demand inay not occur until years after a plan termination, the hien arises as of the plan termination date ${ }^{37}$ and, in general, has the same priority as a tax hen. ${ }^{38}$

\section{F. Liability of Controlled Group.}

Section 4001(b) provides that all trades or busimesses that constitute a controlled group under section 414 of the Code are to be treated as a single employer for Title IV purposes. Based on section 4001(b), the PBGC has taken the position that a plan maintained by a controlled group of employers is a single einployer plan, that the thirty percent of net worth limitation on employer hability is based upon the

number of terminated participants is less than $20 \%$ of the aggregate number of participants under all of the employer's plans. PBGC Opinion Letter 77-123 (Jan. 14, 1977). Because a controlled group of corporations is treated under $\$ 4001(\mathrm{~b})$ as a single employer, the sale of one member of the group could apparently come within $\$ 4062(\mathrm{e})$. Note, however, that the mere relocation of a plant will not necessarily trigger application of $\$ 4062(\mathrm{e})$. PBGC Opinion Letter 77-134 (Mar. 8, 1977). 1976).

35. PBGC Opinion Letters 77-147 (May 24, 1977); 76-89 (Apr. 14, 1976); 76-52 (Apr. 14,

36. ERISA § 4068(a).

37. ERISA \& 4068(b).

38. ERISA \& 4068(c). 
net worth of the controlled group, and that the entire controlled group is liable with respect to any liability incurred by a member of that group under Title IV. ${ }^{39}$

\section{G. Liability of Successor Corporations.}

Liability incurred by a corporation under Title IV may become a liability of a successor corporation (whether or not affiliated with the predecessor corporation) under section 4062(d). ${ }^{40}$ That section provides that if an employer ceases to exist because of a reorganization that involves a mere change in identity, form or place of organization, the successor corporation sliall be treated as the employer; or, if an employer ceases to exist by reason of a liquidation into its parent corporation, the parent shall be treated as the employer; or, if the employer ceases to exist by reason of a merger, consolidation or division, the successor corporation or corporations shall be treated as the einployer.

In addition, the liability incurred by a successor corporation under a plan established by it nay be affected in limited circumstances by its predecessor's plans. Section 4021(a) provides that, for purposes of Title IV, a plan which covers a group of employees which includes substantially the same einployees as a previously established plan and provides substantially the same benefits, will be treated as a continuation of the previously established plan. Such treatment may affect the amount of the successor employer's plan benefits guaranteed under the five-year pliase-in rule.

A corporation that is acquiring assets only does not coune within the provisions of section 4062(d) and, if it does not continue the transferor's plan and is not a nember of a controlled group which includes the transferor corporation, the acquiring corporation should incur no liability under Title IV by reason of the termination of a plan by the transferor, wliether prior to or subsequent to the purchase of assets. ${ }^{41}$

\section{H. Liability of Transferor Corporations.}

If a corporation witldraws froun a plan to which inore than one employer contributes, it will be subject to liability under Title IV

39. Temporary Regulations, 29 C.F.R. § 2612.1 (1978); PBGC Opinion Letter 77-158, (Aug. 15, 1977). See also PBGC v. Ouinient Corp., CA 76-1314-T, 77-2004-T (D. Mass. Mar. 22, 1979).

40. While $\S 4062$ does not apply to multiemployer plans, $\S 4064$ (b) (which does apply to such plans) provides that liability of each employer shall be determined in a manncr consistent with $\S 4062$. 1976).

41. PBGC Opinion Letters 78-10 (June 2, 1978); 76-115 (Oct. 27, 1976); 76-111 (Sept. 16, 
(whether or not it is a substantial employer) if the plan should terminate at any time before the end of the fifth plan year following its withdrawal and if plan assets are then insufficient to pay guaranteed benefits. ${ }^{42}$ Thus, a transferor corporation that has withdrawn from a plan on or before the date of a Corporate Transaction may be subject to future liability under Title IV regardless of whether the transferee corporation contributes to the plan.

If a successor corporation does not continue operations at all of the transferor's facilities and, as a result, more than twenty percent of the participants im a pension plan are terminated as of the date of the Corporate Transaction, the transferor corporation nay incur liability under section 4062(e) even though the successor continues the transferor's plan.

Subject to the two exceptions noted below, if the transferee corporation in a Corporate Transaction contimues a simgle employer plan previously maintained by the transferor corporation, the transferor ought not to incur any liability under Title IV by reason of the subsequent termination of that plan. Section 4062, which imposes liability upon the termination of a single employer plan, would have no apphcability to the transferor since, by its terms, it imposes liability only on the "employer who maintamed [the plan] at the time it was terminated." 43 Section 4064, which imposes liability upon the termination of a plan to which inore than one einployer contributes, ought not to apply either. Section 4064(a) provides as follows:

This section applies to all employers who inaintain a plan under which more than one employer makes contributions at the time such plan is terminated, or who, at any time within the 5 plan years preceding the date of termination, made contributions under the plan.

The foregoing language leaves some ambiguity as to whether section 4064 has application to a plan to which successive employers have contributed, but to which no more than one employer has contributed at one time. The Conference Committee report, which provides that section 4064 is to apply to "plans having more than one employer making contributions at the time of the termination, or at any time within the five plan years preceding the date of termination," 44 appears to resolve that ambiguity against such application.

There are two exceptions under which a transferor corporation nay incur hability upon the termination of a plan subsequent to a Corporate Transaction. The first such exception occurs where the trans-

42. ERISA § 4064.

43. ERISA $\S 4062$ (a) (emphasis added).

44. H.R. ReP. No. 1280, 93d Cong., 2d Sess. 380 (1974). 
feror and transferee corporations are members of a controlled group of corporations. ${ }^{45}$ The second exception occurs where the PBGC institutes proceedings to terminate the plan under section 4042(a), for exainple, when there is an increased possibility of long-run loss to the PBGC because the transferee is not financially sound, and the date of plan termination established by the court is prior to the date of the Corporate Transaction. ${ }^{46}$

The PBGC has issued opinion letters that a transferor corporation will have no continuing liability for a plan that is continued by a transferee corporation if, as of the date of the Corporate Transaction, eitlier the plan assets are sufficient to pay guaranteed benefits, or thirty percent of the net wortli of the transferee corporation is greater than the amount of insufficiency. ${ }^{47}$ Such letters suggest by negative inuplication that, but for the sufficiency of plan assets or the successor's net worth, the transferor corporation could be liable on a subsequent plan termination; however, no authority is cited in the letters for any such liability.

\section{Minimum Participation Standards}

A Corporate Transaction inay affect a plan's coinphance with the minimum participation standards established by section 410 of the Code in two ways. First, for purposes of determining whether an employee lias met a plan's minimuin service requireinents, service with the predecessor employer prior to the Corporate Transaction inay have to be treated as service with the successor employer inaintaining the plan. Second, the application of the minimum coverage requirements of section 410 inay be significantly affected by the Corporate Transaction.

\section{A. Service with a Predecessor Employer.}

Under section 410(a) of the Code, an employer inay require an employee to complete a minimum period of service in order to participate in a plan inamtained by the employer. However, in the case of an employer that maintains the plan of a predecessor einployer, service with the predecessor must be treated as service with the employer. ${ }^{48}$ In the case of an employer that does not inamtam a predecessor einployer's plan, service with the predecessor must be taken into account if required by regulations to be issued by the Secretary of the Treasury.

45. See text accompanying note 39 supra.

46. See notes 26-27 supra and accompanying text.

47. PBGC Opinion Letters 78-29 (December 12, 1978); 78-9 (June 19, 1978); 78-7 (May 25, 1978); 77-167 (Oct. 13, 1977); 77-147 (May 24, 1977).

48. See text accompanying notes $91-93$ infra. 


\section{B. Coverage Tests.}

While a qualified plan need not cover all employees of the employer maintaining it, coverage under the plan (or under two or more plans designated as a single plan for these purposes) ${ }^{49}$ must meet one of two alternative tests set forth in section $410(\mathrm{~b})$ of the Code on at least

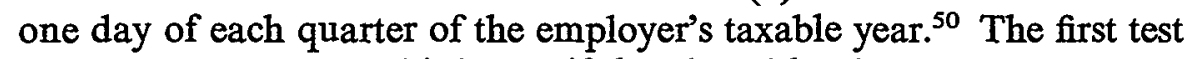
is an objective test, and it is met if the plan either benefits at least seventy percent of the employees or benefits at least eighty percent of ail eligible employees and at least seventy percent of the employees are eligible. The second test is subjective in nature, and it is met if the plan benefits employees in a classification that the Secretary of the Treasury finds does not discriminate in favor of employees who are officers, shareholders or highly compensated. Under the objective test, employees who have not met the plan's minimum age and service requireinents may be disregarded. Under either test, union employees may be disregarded if retirement benefits have been the subject of good faith bargaining.

The coverage tests and their apphication to controlled groups of corporations will not be discussed in detail in this Article. ${ }^{51}$ However, certain aspects of the application of these tests within a Corporate Transaction setting will be noted. First, in general, the employees of all corporations that are members of a controlled group must be taken into account for purposes of applying the coverage tests to any plan maintained by a member of that group. ${ }^{52}$ However, the preceding requireinent applies in any plan year only with respect to those corporations that are nembers of the controlled group on at least one day in each quarter of that plan year. ${ }^{53}$ Accordingly, in many situations the manner in which a Corporate Transaction is structured may significantly affect the date as of which one or more plans will have to be amended to comply with section 410 . For example, assume first, that corporation A (with a calendar-year tax year) maintains a plan (with a calendaryear plan year) which is unable to meet the classification test but does meet the percentage test; second, that corporation $\mathrm{A}$ wants to acquire corporation B, which maintams no plan, on January 2, 1980; and finally, that when corporation B's employees are considered, corporation A's plan will meet neither the percentage test nor the classification

49. See Treas. Reg. $\& 1.410(b)-1(d)(3)$ (1978).

50. I.R.C. \& 401(a)(3), (6).

51. See Cook, Unresolved Questions for the Controlled Group of Corporations, 1979 DuKE L.J. 539.

52. I.R.C. \& 414(b); Treas. Reg. \& 1.410(b)-1(d)(8) (1978).

53. Treas. Reg. \& 1.410(b)-1(d)(8) (1978). 
test unless it is amended to mcrease participation, or unless a comparable plan is established and the two plans are designated as a smgle plan for purposes of section 410 . If corporation $B$ is merged into an existing subsidiary of corporation A on January 2, 1980, participation under corporation A's plan must be expanded by no later than June 30, 1980 (the last day of its next taxable year quarter). On the other hand, if a new subsidiary of corporation A is formed on January 2, 1980, and corporation $B$ is nerged into the new subsidiary, coverage under corporation A's plan need not be expanded until March 31, 1981 (the last day of the taxable year quarter which includes the first day of the first plan year during which $A$ and $B$ will be members of a controlled group on at least one day in each plan year quarter).

Second, it should not be assumed that a plan (or plans) which met the coverage tests of section 410 when maintained by a transferor corporation will meet the coverage requirements when maintained by a successor corporation. For example, assume that corporation $\mathrm{C}$ inaintains a plan for all salaried employees which benefits seventy percent of all nonunion employees and maintains no plan for its nonunion hourly employees, and that corporation $\mathrm{C}$ incorporates and spims off one of its divisions, fifty percent of whose einployees are salaried employees and fifty percent nonunion hourly enployees. Although corporation $\mathrm{C}$ could maintain a salaried-only plan because it met the seventy percent test, the corporation which was spun off will not be able to inaintain a salaried-only plan unless it establishes a coinparable plan for hourly employees.

Third, a plan inaintained by a transferor corporation which meets the coverage test before a Corporate Transaction may not meet the coverage test after the Corporate Transaction. For example, if corporation $C$ in the preceding example had spun off a division consisting entirely of salaried and union employees, after the spin off its plan might no longer cover seventy percent of its nonumion employees.

Finally, if the parties to a Corporate Transaction intend to freeze a plan, that is, to discontinue further benefit accruals, care must be taken that the plan does not become disqualified because of discrimination in operation resultimg froin the termination of lower-paid participants or, if withdrawal of benefits is permitted, the disproportionate withdrawal of benefits by low-paid participants. ${ }^{54}$

\section{Additional Vesting}

A Corporate Transaction may affect vesting both under plans

54. Treas. Reg. § 1.401-1(b)(4) (1978); Rev. Rul. 57-587, 1957-2 C.B. 260. 
maintained by the transferor or predecessor corporation and under plans maintained by the transferee or successor corporation. Plans maintained by a transferor or predecessor corporation are most likely to be affected by the requirement imposed by section 411(d)(3) of the Code that benefits must be fully vested upon the termination or partial termination of a plan or upon the complete discontinuance of contributions to a plan. Plans maintained by a transferee or successor corporation are inost likely to be affected by the rules dealing with service for predecessor einployers, service prior to the establishment of a plan and changes in vesting schedules.

\section{A. Termination, Partial Termination or Discontinuance of Contributions.}

1. General. Under section 411(d)(3) of the Code, every qualified plan inust provide that the accrued benefits of all affected employees will be nonforfeitable, to the extent they are funded, as of the date the plan is terminated or partially terminated. ${ }^{55}$ In addition, a stock bonus or profit sharing plan must provide that accrued benefits will be nonforfeitable as of the date contributions to the plan are completely discontinued. While similar vesting requirements were in effect prior to ERISA, the application of the requirements in some situations differs significantly following enactment.

The determination of whether a "plan" maintamed by a controlled group of corporations is a single plan or a group of plans is central to determining the application of section 411(d)(3). For example, if one member of a controlled group is acquired by outside interests and therefore "withdraws" froun a pension plan unaintained by the controlled group, the application of section 411(d)(3) unay depend upon whether there has been a termination of a single plan unaintained by that member or, mstead, a possible partial termination of the controlled group plan. ${ }^{56}$

Also important in many Corporate Transactions is the determination of whether a plan is "mamtained pursuant to an agreement which the Secretary of Labor finds to be a collective bargaining agreement . . . ."57 If it is such a plan, section 413(b)(2) of the Code provides that section 411(d)(3) will be applied separately to each group of partici-

55. In the case of a defined benefit plan, the extent to which plan benefits are funded is determined by apphication of the allocation rules set forth in ERISA § 4044. H.R. REP. No. 1280, 93d Cong., 2d Sess. 277 (1974); Treas. Reg. § 1.411(d)-2(a)(2)(ii) (1978).

56. For a discussion of the single plan/multiple plan issue, see text accompanying notes 7-10 supra.

57. I.R.C. § 413(a)(1). 
pants covered under a separate benefit formula. In some cases such an application will result in a partial termination where none would have occurred otherwise. ${ }^{58}$ In other cases, apphication of section 411(d)(3) on a benefit structure basis may prevent a partial termination as to some participants which would otherwise occur. ${ }^{59}$

The application of section 411(d)(3) in a Corporate Transaction context will also depend upon which of several alternatives is undertaken with respect to the transferor's qualified plans as they apply to employees transferred to the successor. These alternatives include continuation of the plans by the successor; inerger of the plans into one or inore plans maintained by the successor; replacement of the plans with plans of the successor; discontinuance of accruals under a defined benefit pension plan; and discontinuance of contributions under a defined contribution plan.

Benefits of employees who are not transferred to the successor corporation may also be affected by virtue of the Corporate Transaction. For example, employees whose employment with the transferor corporation is severed as a result of the Corporate Transaction may not be hired by the suceessor corporation, or a transferor corporation may decide to terminate a plan or inerge it imto another plan if a majority of the participants are transferred to the successor. Accordingly, the primciples discussed below with respect to transferred employees may also have apphication to other employees whose plan benefits are affected as a consequence of the Corporate Transaction.

2. Continuation of Plans. If the successor corporation in a Corporate Transaction continues the plan as applied to all transferred einployees without curtailing eligibility, benefits or vesting, ${ }^{60}$ there will be no necessary termination or partial termination of the plan as apphied to those employees. However, care must be taken to assure that the

58. For example, a single employer may maintain a collectively bargained plan with different benefit structures for the various occupations represented by the union. If the employees in one such occupation are employed primarily at one plant and that plant is sold, there inay be a partial termination of the plan as applied to those employees even though the plant is so small that if all employees were considered there would be no partial termination.

59. For example, if one employer withdraws fron a collectively bargained plan, that withdrawal may be significant enough that in the absence of $\$ 413(b)(2)$ it would be treated as a partial termination as to all of the withdrawing employer's employees, and yet as to one particular benefit structure the withdrawing employer's employees may represent such a small percentage that under $\S 413(\mathrm{~b})(2)$ there is no partial termination as to them.

For convenience, the term "plan" is used in the remainder of this subpart V A to refer both to an entire plan and, where applicable, to a portion of a collectively bargained plan covered by a separate benefit structure.

60. For a discussion of the effects of curtailing eligibility, benefits or vesting under a plan, see text accompanying notes $69-73$ infra. 
transferor's plan (and any applicable trust or insurance contract) does not provide for autornatic termination upon the occurrence of the Corporate Transaction. If aunendments are necessary to prevent an automatic termination, they inust be adopted prior to the date of the Corporate Transaction.

If the successor corporation continues the transferor's plan for only a portion of the participants, for example, if less than all employees are transferred or if the transferor continues the plan as applied to former employees, the splitting of plan assets and liabilities inust, of course, comply with section 208 of ERISA and section 414(1) of the Code.

3. Plan Merger. As an alteruative to the successor continuing the transferor's plans for the benefit of transferred einployees, the parties inay cause the transferor's plans to be merged into one or nnore of the successor's plans im accordance with sections 208 of ERISA and 414(1) of the Code. The application of section 411(d)(3) in a plan inerger context depends upon the type of plans inerged and whether or not there has been a curtailment of the eligibility, benefits or vesting provisions by virtue of the inerger.

(a) Type of plans. Treasury regulations issued prior to ERISA provided that a plan would not be considered terminated if it were consolidated with a "coinparable" plan. ${ }^{61}$ For this purpose, the regulations stated that defined benefit pension plans, annuity plans and money purchase pension plans were coinparable plans, and that profit sharing plans and stock bonus plans were also comparable. ${ }^{62}$ Thus, under the pre-ERISA rules, if a defined benefit pension plan and a money purchase pension plan were inerged, there would be no termination. Similarly, if a stock bonus plan and a profit sharing plan were merged there would be no termination. However, unless the Commissioner exercised his discretion to determine that other plans were comparable, ${ }^{63}$ a merger of a pension plan into a stock bonus or profit sharing plan would result in a termination of the pension plan, and a merger of a stock bonus or profit sharing plan into a pension plan would result in the termination of the stock bonus or profit sharing plan. ${ }^{64}$

While not withdrawn, the foregoing pre-ERISA regulations appear to have been superseded by regulations issued under section

61. Treas. Reg. $\$ 1.401-6(b)(1)$ (1963).

62. Treas. Reg. $\S \S 1.401-6(b)(1), .381(c)(11)-1(d)(4)(1963)$.

63. Treas. Reg. $\S 1.401-6(b)(1)(1963)$.

64. Rev. Rul. 67-213, 1967-2 C.B. 149. 
411(d)(3). ${ }^{65}$ Under the latter regulations, a plan which is subject to Title IV of ERISA, that is, a defined benefit pension plan, will be treated as terminated for section 411 purposes when it is terminated for Title IV purposes. ${ }^{66}$ When a defined benefit pension plan is merged into a money purchase pension plan, it is treated as terminated under section 4041(f) of ERISA and, contrary to the pre-ERISA regulations, it will be treated as terminated for section 411 purposes. Because a merger of defined benefit pension plans is not treated as a termination under Title IV, however, a merger of two defined benefit plans will not be treated as a termination of either plan. Under the final regulations, a plan which is not subject to Title IV is considered terminated as of the date it is "voluntarily terminated by the employer." 67 Thus, if, instead of being terminated, a defined contribution plan is converted or merged into another plan (whether or not "coinparable" under pre-ERISA regulations and rulings), for example, a money purchase pension plan merged into a profit sharimg plan, then there ought to be no termination, although there nay be a partial termination if there is a curtailment of eligibility, benefits or vesting. ${ }^{68}$

(b) Curtailment of eligibility, benefits or vesting. Pre-ERISA regulations provided that "whether or not a partial termination occurs when benefits or employer contributions are reduced, or the eligibility or vesting requirements under the plan are made less liberal, will be determined on the basis of all the facts and circumstances." 69 Because of the paucity of published rulings in this area, it was difficult to formulate

65. Pre-ERISA Treas. Reg. $\S 1.401-6$ interpreted section 401(a)(7) of the Code which, prior to ERISA, required full vesting on termination or partial termination of a plan. Since section 401(a)(7), as amended by ERISA, now requires vesting on termination or partial termination only to the extent required by section 411 , it would seem that Treas. Reg. $\S 1.401-6$ should be entirely superseded by the regulations issued under section 411 . Nevertheless, private letter rulings continue to refer to it. See, e.g., I.R.S. Private Letter Rulings 7909084, 7904071, 7902030, [1979] FED. TAXEs (P-H) Tf 840, 362, 60; Private Letter Rulings 7852110, 7829019, 1978 Fed. Taxes Private Letter Rulings (P-H) Tा 4616, 2365.

66. Treas, Reg. § 1.411(d)-2(c)(2) (1977).

67. Treas. Reg. $\& 1.411$ (d)-2(c)(3) (1977).

68. It is possible for the IRS to take the position that because of the basic differences between "noncomparable" plans, the merger of two such plans is a voluntary termination of one. See, e.g., Rev. Rul. 67-213, 1967-2 C.B. 149. However, the deletion of the comparability-of-plan language from section 411 regulations and the fact that the merger of "comparable" plans is not treated as a voluntary termination, suggest that a merger of noncomparable plans was not intended to be considered, per se, to be a termination of one of the plans for vesting purposes. Of course, a merger of noncomparable plans may be treated as a partial termination if, because of the different nature of the plans, there is a curtailment of benefits. The merger of noncomparable plans might also preclude the use of contribution carryforwards and deduction carryovers. See text accompanying notes $91-100$ infra.

69. Treas. Reg. § 1.401-6(b)(2) (1963). 
concrete guidelines as to when a plan would be considered partially terminated pre-ERISA. Generally, a significant reduction in the level of plan benefits would result in a partial termination; however, if eligibility requirements were liberalized at the time the level of plan benefits was reduced and, as a result, einployer contributions were increased, then there might be no partial termination. ${ }^{70}$ If a partial termination occurred, full vesting as to the part of the plan that terminated was required under the pre-ERISA regulations. ${ }^{71}$

Like the pre-ERISA regulations, the regulations issued under section 411(d)(3) provide that "whether or not a partial termination of a qualified plan occurs (and the time of such event) shall be determined by the Commissioner with regard to all the facts and circumstances in a particular case."72 However, those regulations also provide the following significant exception, representing a change from the pre-ERISA regulations, with respect to any decrease in benefit accruals:

If a defined benefit plan ceases or decreases future benefit accruals under the plan, a partial termination shall be deemed to occur if, as a result of such cessation or decrease, a potential reversion to the employer, or employers, maintaining the plan (determined as of the date such cessation or decrease is adopted) is created or increased. If no such reversion is created or increased, a partial termination shall be deemed not to occur by reason of such cessation or decrease. ${ }^{73}$

It appears, therefore, that under the section 411 regulations the merger of one defined benefit pension plan into another defined benefit pension plan will not result im a termination and will result in a partial termination only if there is a potential reversion or if eligibility or vesting provisions are curtailed; that the merger of a defined benefit pension plan into any other type of plan, including a inoney purchase pension plan, will result in the termination of the defined benefit plan; and that the merger of a defined contribution plan into any other plan (whether or not comparable) will not result in a termination but may result in a partial termination if eligibility, benefits or vesting are curtailed. As in the case of a successor corporation continuing the plans of a transferor corporation, the parties must take care to comply with the provisions of any applicable trust or insurance contract.

70. Rev. Rul. 73-535, 1973-2 C.B. 140.

71. For example, if a defined benefit pension plan providing a benefit of two percent of coinpensation per year of service were merged into another defined benefit pension plan providing a benefit of $1.25 \%$ of coinpensation per year of service, the benefits accrued under the inerged plan as of the date of merger and attributable to the additional three-fourths of one percent benefit under that plan would be required to be fully vested.

72. Treas. Reg. $\S 1.411(\mathrm{~d})-2(\mathrm{~b})(1)(1977)$.

73. Treas. Reg. $\$ 1.411(\mathrm{~d})-2(\mathrm{~b})(2)(1977)$. 
4. Replacement of Plans. In lieu of the successor either continuing all or a portion of the transferor's plans or merging all or a portion of the transferor's plans with its own plans, the parties to a Corporate Transaction may agree that the successor will establish its own plan for the transferred employees. Treasury regulations issued prior to ERISA provided that a plan would not be considered terminated if an acquiring corporation replaced it with a coinparable plan; however, there might be a partial termination if eligibility, benefits or vesting were curtailed. ${ }^{74}$ However, as discussed in paragraph three of this section, the pre-ERISA regulations have apparently been superseded by regulations issued under section 411 (d)(3). Under the section 411 (d)(3) regulations, if a defined benefit pension plan is terminated for Title IV purposes it will be treated as terminated for section 411 purposes regardless of whether the successor replaces it with a plan of its own. ${ }^{75}$ Similarly, $m$ the case of a defined contribution plan, a termination will occur for section 411 (d)(3) purposes on the date the plan is voluntarily terminated by the employer, regardless, apparently, of whether a successor replaces it. ${ }^{76}$

Whether a partial termination occurs with respect to either a defined contribution plan or a defined benefit plan depends on the facts and circuunstances of the case $; 7$ however, there is no suggestion in the regulations that the actions of a successor corporation im replacing a plan will affect the determination of whether the transferor's plan has been partially terminated. Paragraphs five and six below discuss what constitutes a termination for Title IV purposes and some of the facts and circumstances which might cause a partial termination.

5. Discontinuance of Accruals Under a Defined Benefit Plan. The parties to a Corporate Transaction might well agree that the transferor will cease all benefit accruals for the transferred einployees as of the date of the Corporate Transaction and that the successor will not be obligated to provide any retirement benefits for the transferred einployees. Prior to ERISA, the transferor's plan im such a situation would be treated as partially terminated as applied to the transferred einployees or terminated entirely if all participants were affected. The transferor could cease both benefit accruals and contributions and all affected participants would be vested to the extent that their benefits were

74. Treas. Reg. $\$ 1.401-6(b)(1)-(2)(1977)$; see text accompanying notes $61-63$ supra for a description of comparable plans.

75. Treas. Reg. $\$ 1.411(d)-2(c)(2)$ (1977).

76. Treas. Reg. $\$ 1.411(d)-2$ (c)(3) (1977).

77. Treas. Reg. $\$ 1.411(\mathrm{~d})-2(\mathrm{~b})(1)(1977)$. 
funded.

The post-ERISA effects of such an agreement will depend upon which of two alternative courses of action the transferor pursues. If the transferor terminates the plan in accordance with Title IV of ERISA, it will be relieved of any further contributions to the plan (subject, of course, to the requirements of section 412 for plan years beginning prior to the termination and to any hability imcurred under Title IV) and participants will be vested in accordance with section $411(\mathrm{~d})(3){ }_{.}^{78}$

Alternatively, the transferor may "freeze" the plan benefits of affected participants, that is, continue to fund the benefits already accrued but cease accruals as of the date of the Corporate Transaction. The PBGC has taken the position that a freezing of plan benefits is not a termination for Title IV purposes, ${ }^{79}$ and accordingly it should not be treated as a termination under the section $411(\mathrm{~d})(3)$ regulations discussed above. Even though no termination results from the freezing of plan benefits, there may be a partial termination. The section 411(d)(3) regulations indicate clearly that, unless a potential reversion to the employer is created or increased, the freezing of plan benefits will not, by itself, cause the plan to be treated as partially terminated, but that other facts and circumstances may cause the plan to be so treated. ${ }^{80}$ Such facts and circumstances include "the exclusion, by reason of a plan amendment or severance by the employer, of a group of employees who have previously been covered by the plan; and plan amendments which adversely affect the rights of employees to vest in benefits under the plan." 81 While it might be argued that the cessation of future accruals must in all cases result in the "exclusion . . . of a group of employees who have previously been covered by the plan,"82 and therefore raise the potential of a partial termination, such an interpretation would nullify the special rule which provides that a plan is not to be treated as partially terminated merely because of the cessation of benefit accruals.

As long as the employer continues to fund frozen accruals, participants who are vested are benefiting from the employer's contributions and should not be viewed as excluded from the plan. On the other

78. If less than all of the active participants in the transferor's plan are affected by the Corporate Transaction, the transferor may cause a termination of the plan as applied to the affected participants by first spinning off that portion of the plan in accordance with regulations issued under $\$ 414(1)$ of the Code and then terminating the spun-off plan.

79. PBGC Opinion Letters 76-77, (June 10, 1976); 76-71 (May 16, 1976); 76-39 (Mar. 19, 1976); PBGC Publication No. PBGC 503.

80. Treas. Reg. \& 1.411(d)-2(b)(2) (1977).

81. Treas. Reg. \& 1.411(d)-2(b)(1) (1977).

82. Id. 
hand, participants who are not vested and who receive no vesting credit after the Corporate Transaction might be viewed as having been excluded from the plan and, if their numbers are large enough, the plan might be viewed as partially terminated. If, however, full vesting credit is given for service with the successor corporation, and the benefits of transferred employees under the transferor's plan continue to be funded, the situation is essentially the same as if the employees reinained with the transferor and the transferor merely ceased further benefit accruals. Absent special facts and circumstances there appears to be hittle basis for a finding that such a defined benefit pension plan has been partially terminated as applied to the transferred einployees.

\section{Discontinuance of Contributions Under a Defined Contribution} Plan. If a transferor corporation's defined contribution plans, as they apply to employees transferred to the successor, are not contimued by the successor corporation or merged into the successor's plans, no further contributions will be made on behalf of the transferred employees. The resulting exclusion of the former participants in the transferor's plans may cause a partial termination of the plan.

Post-ERISA regulations ${ }^{83}$ are substantially the saine as preERISA regulations ${ }^{84}$ with respect to the partial termination of a plan by virtue of the exclusion of former participants. Both state that the determination will be based on all the facts and circumstances. Because of the paucity of published rulings discussing the apphication of the facts and circumstances test, it is difficult to develop guidelines as to the nature of exclusions which will or will not result in a determination that a plan has been partially terminated. ${ }^{85}$ A practitioner will, however, want at least to consider the total number of einployees excluded, the percentage they constitute of all participants, and whether they constitute a distinct group, such as all of the employees at a single division

83. $I d$.

84. Treas. Reg. \& 1.401-6(b)(2) (1963).

85. There are only three Revenue Rulings applying the facts and circumstances test and each involved the exclusion of more than fifty percent of the plan's participants. In Rev. Rul. 72-439, 1972-2 C.B. 233, an employer's nonsalaried employees were unionized. Pursuant to the union contract, the umionized employees were excluded from participation in future contributions to the employer's profit sharing plan. The IRS held that the exclusion of the 120 unionized participants out of 170 total participants resulted in a partial termination of the plan. In Rev. Rul. 72-510, 1972-2 C.B. 223, the IRS held that the discharge of ninety-five out of 165 participants in a pension plan pursuant to the closing of one division of the employer resulted in a partial termination of the plan. In Rev. Rul. 73-284, 1973-2 C.B. 139, twelve out of an émployer's fifteen employees declined transfers to the employer's new location. The IRS held that the discharges resulted in the partial termination of the einployer's pension plan. 
or single location of an employer. ${ }^{86}$

7. Time of Termination or Discontinuance and Affected Employees. If it is determined that a plan has terminated or partially terminated or that contributions have been completely discontinued, two additional issues are raised with respect to the application of section 411(d)(3). First, what is the date of the termination, partial termination or discontinuance? Second, who are the affected employees?

With respect to the first issue, it would seem that the applicable date would be readily determinable in most Corporate Transaction situations; however, two situations are worthy of note. First, the date on which a defined benefit pension plan is terminated is determined in accordance with section 4048 of ERISA, ${ }^{87}$ that is, the date agreed to between the plan administrator and the PBGC or, if they do not agree, the date established by the court. ${ }^{88}$ Second, pre-ERISA regulations provided that a plan is terminated when, in connection with the winding up of the einployer's trade or business, the employer begins to discharge his employees. ${ }^{89}$ While that is no longer the governing rule with respect to plan terminations, the IRS might now take the position that, under the facts and circumstances of a particular Corporate Transaction, a partial termination occurred when the employer began to terminate its employees.

There is little difficulty in determining the affected employees in most Corporate Transaction situations. However, the treatment of former einployees who still have plan interests deserves special consideration. Section 411(d)(3) appears to require full vestimg for employees only. Thus, it would seein possible to forfeit the plan interests of former employees to the extent they had not already vested. Since service after a plan has been terminated may be disregarded for vesting purposes, ${ }^{90}$ even the nonvested portion of account balances under a defined contribution plan of former employees who have not yet incurred

86. In practice, a discharge of employees "across the board" may be less likely to result in a partial termination than the discharge of a similar number of employees constituting a distinct division or working at a single location. However, the fact that the discharged employees constitute an entire division or location of an employer does not necessarily dictate the conclusion that there has been a partial termination of the qualified plans covering the employees. See, e.g., Special Ruling Sept. 1, 1978, [1978] Pens. Plan Guide (CCH) I 17,367S; IRS Private Letter Ruling 7723025, 1977 Fed. Taxes Private Letter Rulings (P-H) I 1086.

87. Treas. Reg. \$ 1.411(d)-2(c)(2) (1977).

88. See text accompanying note 20 supra.

89. Treas. Reg. $\$ 1.401-6(b)(1)$ (1963) (emphasis added).

90. Treas. Reg. \& 1.411(a)-5(b)(3)(iii) (1977). The legislative history is clear that service could be disregarded if contributions were discontinued, even if the plan were kept in existence for the purpose of paying benefits already earned. H.R. REP. No. 807, 93d Cong., 2d Sess. 56 (1974). 
a one-year break in service ought to be forfeitable. Nevertheless, vesting of the account balances of former einployees that have not yet been forfeited nay be prudent in certain situations in view of the possible assertion by the IRS that a partial termination occurred prior to the coinplete termination of the plan.

\section{B. Service with Predecessor Employers, Service Prior to the Establishment of a Plan and Changes in Vesting Schedules.}

1. General. Three vesting provisions of the Code are likely to affect the plans mamtained by successor corporations in Corporate Transactions. Those provisions are section 414(a) dealing with service with a predecessor employer, section $411(\mathrm{a})(4)(\mathrm{C})$ dealing with vesting service for periods during which a plan is not maintained, and section 411(a)(10) dealing with changes in vesting schedules.

2. Predecessor Employers. Section 414(a) provides as follows:

(a) SERVICE FOR PREDECESSOR EMPLOYER-For purposes of this part-

(1) in any case in which the einployer inaintains a plan of a predecessor einployer, service for such predecessor shall be treated as service for the employer, and

(2) in any case in which the employer maintains a plan which is not the plan maintained by a predecessor employer, service for such predecessor shall, to the extent provided in regulations prescribed by the Secretary, be treated as service for the einployer. ${ }^{91}$

As of this writing, the IRS has not promulgated regulations under section 414(a). Until it does, the application of that section to many Corporate Transactions will remain uncertain. Unanswered questions include how the regulations will define a predecessor employer, that is, whether, regardless of the nature of the Corporate Transaction, a transferor corporation will always be treated as a predecessor employer, and the extent to which the IRS will require service with a predecessor employer to be credited by a successor which does not contimue the predecessor's plan. Another uncertainty exists with regard to what will constitute maintenance of the predecessor's plan. The Conference Committee report states that a successor employer cannot evade the requirement of section 414(a) by nominally discontmuing the predecessor's plan. ${ }^{92}$ It appears, therefore, that service with a predecessor may also have to be credited when the successor replaces the predecessor's plan with a comparable plan of its own, as well as where a successor

91. I.R.C. \& 414(a).

92. H.R. REP. No. 1280, 93d Cong., 2d Sess. 264, 270 (1974). 
continues the predecessor's plan or merges it into a plan of its own. A final question concerns whether service with the predecessor must be credited solely for purposes of the predecessor's plan that is bemg maintained by the successor or also for the purpose of any other quahfied plan maintained by the successor for which former employees of the predecessor employer are eligible. Since the primary purpose of section 414(a) is to prevent an employee from losmg his vestimg rights as a result of a business reorganization, ${ }^{93}$ it would seem that the regulations ought not require that predecessor employer service be credited for purposes of qualified plans other than a plan which is a continuation of or replacement for the predecessor's plan.

3. Periods During Which a Plan Is Not Maintained. Section 411(a)(4)(C) provides that, for vesting purposes, a plan may disregard years of service with an employer for any period during which the employer did not maintain the plan or a predecessor plan. Under this section, service completed prior to the first day of the plan year in which a plan is adopted, ${ }^{94}$ as well as service completed after the termination date of a plan, ${ }^{95}$ may be disregarded.

If an employer terminates a qualified plan after the effective date of section 411 as apphed to that plan, and another qualified plan is established by that employer within either the five-year period preceding or the five-year period following the termination date, the terminated plan will be treated as a predecessor plan with respect to employees covered under both it and the successor plan. ${ }^{96}$

The application of section 411(a)(4)(C) to employees covered under a plan is generally dependent upon the date their employer adopts the plan, regardless of whether the plan has been previously adopted by other employers. ${ }^{97}$ In the case of a transfer of plan assets or liabilities (mcluding a merger or consolidation of plans) involving two plans mamtained by one employer, the successor or transferee plan is treated as if it were established at the same time as the earliest component plan. If the plans were maintained by two or more employers, the successor or transferee plan is treated as if it were established on each of the separate dates on which the component plans were established

93. H.R. REP. No. 807, 93d Cong., 2d Sess. 58 (1974).

94. Treas. Reg. \& 1.411(a)-5(b)(3)(ii) (1977).

95. Note, however, that a plan may be treated as being maintained after its termination date if contributions are continued, whether or not benefit accruals are stopped. Treas. Reg. $\S 1.411$ (a)5(b)(3)(iii) (1977).

96. Treas. Reg. $\S 1.411(a)-5(b)(3)(v)(A)$, (B) (1977).

97. Treas. Reg. \& 1.411(a)-5(b)(3)(ii) (1977). 
for the employees of each employer..$^{98}$

4. Changes in Vesting Schedules. The merger of a transferor corporation's qualified plan into a plan of the successor corporation will often result in a change in the vesting schedule of one of the plans. Even if a successor contimues to maintain a transferor's plans, it inay change the vesting schedule to effect uniformity with the other plans it maintains.

Section 411(a)(10) imposes two restrictions on any such vesting schedule changes. First, the change cannot reduce the vesting percentage applicable to any participant's benefits at the tine of the change. Second, any participant with five or inore years of service must be given the right to elect to continue to have his vesting percentages determined under the vestimg schedule as in effect prior to the change. ${ }^{99}$

Any plan ainendment which directly or indirectly affects the determination of a participant's vesting percentage is subject to section 411(a)(10). ${ }^{100}$ Accordingly, even if the transferor and successor plans have the same basic vesting schedule, for example, full vestimg after ten years of service, an election may have to be provided if the method of determining service under one of the plans is changed, for example, from a basis of hours of service to a basis of elapsed tinne.

\section{Funding ANd Deductibility of Contributions}

\section{A. Minimum Funding Standards.}

Section 412 of the Code imposes minimum funding standards on inost defined benefit pension plans, money purchase pension plans and annuity plans. ${ }^{101}$ In general the apphication of those standards will not be significantly affected by a Corporate Transaction; however, certain aspects of their application inay be important to a party to the transaction.

Most important is the fact that the partial termination of a plan as applied to a group of participants does not end the requirement that the benefits of those participants continue to be funded; that is, the benefits of affected participants cannot be limited on a partial termination to the extent that they are funded as of that date. ${ }^{102}$ For example, if a

98. Id.

99. Of course, no election is necessary if the participant's vested percentage can never be less after the change to the vesting schedule than it would be if the schedule were not changed. Treas. Reg. \& 1.411(a)-8(b)(1) (1977).

100. Treas. Reg. \& 1.411 (a)-8(c) (1977).

101. See I.R.C. $\$ 412(\mathrm{~h})$ for exceptions to this general requirement.

102. Treas. Reg. $\& 1.411$ (a)-4(a) (1977). 
controlled group of corporations maintains a simgle plan and one member of the group withdraws from the plan, then, unless the plan is split in accordance with section 414(1) (and the applicable portion either continued or terminated by the withdrawing member), the benefits of the witlidrawing meinber's employees must continue to be funded by the remaining members. ${ }^{103}$

A second area of possible concern to the parties in a Corporate Transaction is the application of section 412 in the year in which a plan terminates. Section 412(b)(2)(B) requires that the amount contributed for each plan year must include anounts necessary both to amortize past service liabilities and separately to amortize experience gams and losses, in each case in equal annual mstallments over various periods. While it may be logical to prorate the required amortization for the short plan year ending on the date of termination, no regulations have as yet addressed the issue. In determining whether a contribution is required for the year in which a plan terminates, it should be noted that Revenue Ruling $77-82^{104}$ permits a contribution to be deducted in one year but credited for minimuin funding purposes in another year. Thus, a contribution made in 1976 but deducted by a calendar year taxpayer in 1975 may be creditcd for the 1976 plan year for purposes of section $412 .{ }^{105}$

If a transferee corporation continues a plan maintained by the transferor corporation and the funding obligation for the plan year during which the Corporate Transaction occurs is allocated between thein, the parties inay be concerned with the imposition of a tax under section 4971 if the minimum funding standards are not met for that plan year. Section 4971 provides that any such tax will be imposed on the einployer responsible for contributimg to the plan. While regulations liave not yet been issued under section 4971, it would seem logical for the IRS to apply rules comparable to those set forth in section $413(c)(5)$ for multiple employer plans, ${ }^{106}$ that is, allocating responsibility first on the basis of delinquent contributions and then proportional to required contributions.

103. I.R.C. $\$ 414$ (b) provides that the funding obligation will be allocated among the members of a controlled group in accordance with regulations to be prescribed by the Secretary of the Treasury.

104. 1977-1 C.B. 121.

105. Id.

106. While $\S 413(\mathrm{c})(5)$ appears broad enough to include a single employer plan maintained by successive einployers, Proposed Treas. Reg. $\S 1.413-2$ (a) states that it is applicable only to multiple-employer plans. 43 Fed. Reg. 38,605 (1978). 


\section{B. Deductibility of Contributions.}

The effects of a Corporate Transaction on the deductibility of contributions to a quahified plan will often depend on whether the Corporate Transaction is a reorganization to which section 381(a) of the Code applies. Accordingly, after discussing the general principles applicable to the deductibility of contributions, this subpart will separately address section 381 transactions and non-section 381 transactions.

1. Deductibility of Contributions Generally. (a) Ordinary and necessary expenses. Contributions to qualified plans are deductible only under section 404 of the Code and only to the extent that they are both ordinary and necessary expenses and reasonable compensation for services actually rendered. ${ }^{107}$ In determining the reasonableness of compensation, all current and deferred compensation and all services rendered to the einployer in prior years as well as the current year are considered. ${ }^{108}$

Prior to ERISA, an employer was generally allowed a deduction for contributions on belialf of its own enployees only. Contributions by one corporation which benefited employees of another corporation were not treated as being for the exclusive benefit of employees under section 401(a)(2) and were not deductible even if the corporations were neinbers of a controlled group of corporations, unless it was not feasible to determine separately the costs of benefits attributable to employees of each contributing einployer. ${ }^{109}$

The extent to which a corporation's post-ERISA plan contributions will be deductible when allocated to employees of another corporation is unclear. ${ }^{110}$ Section $414(b)$ provides, first, that for purposes of section 401, all employees of a controlled group of corporations are to be treated as if they were employed by a single employer and, second, that the section 404(a) limitations will be determined as if all members of a controlled group that have adopted a plan were a single employer, and then allocated to each employer in accordance with regulations to be prescribed by the Secretary of the Treasury. Section 413 of the Code provides similar rules with respect to plans maintained by more than one employer, mcluding but not limited to, collectively bargained

107. Treas. Reg. \& 1.404(a)-1(b) (1961).

108. $I d$.

109. Rev. Rul. 70-532, 1970-2 C.B. 95; Rev. Rul. 69-525, 1969-2 C.B. 102. There were, of course, statutory exceptions under sections 404(a)(3)(B), 406 and 407. In addition, deductions were permitted for contributions to collectively bargained multiemployer plans.

110. See Cook, Unresolved Questions for the Controlled Group of Corporations, 1979 DUKE L.J. 539. 
plans. Proposed section 413 regulations specifically provide that contributions by one employer may be allocated to employees of another employer without violating the exclusive-benefit requirements of section $401(a)(2){ }^{111}$ It would seem likely, therefore, that any regulations issued under section 414(b) (or 404(a)) will provide greater flexibility than the pre-ERISA rules regarding the extent to which contributions to a plan by one inember of a controlled group may be allocated to employees of other members.

(b) Pension and annuity plans. Section 404(a)(1)(A) prescribes three general methods for determining the inaximum deductible contribution to a qualified defined benefit pension plan or a qualified inoney purchase pension plan. Section 404(a)(2) applies the same rules to contributions to a qualified annuity plan. Subject to certain exceptions not important to this discussion, ${ }^{112}$ the maximuin deductible amount for any taxable year under section 404(a)(1)(A) is the greatest of the following: the amount necessary to meet the minimum funding standard provided by section 412 for plan years ending on or before the last day of that year; the annual level cost of the plan; ${ }^{113}$ or an amount equal to the sum of the normal cost for that year plus the amount necessary to amortize past-service costs or supplementary costs over ten years. The portion, if any, of an employer's contribution for a taxable year that exceeds the inaximum deductible anount under section 404(a)(1)(A) or 404(a)(2) results in an excess contribution carryforward. Under section 404(a)(1)(D), the excess contribution carryforward may be deducted in succeeding taxable years to the extent that contributions in such succeeding years are less than the inaximum deductible amounts for such years. Treasury regulations issued prior to ERISA provide that, if the succeeding taxable year ends within a plan year during which the pension trust or annuity plan is not exempt or if it ends after the trust or plan has terminated, the excess contribution carryforward is deductible only to the extent of the maximum permitted under the last alternative above. ${ }^{114}$

If, im any taxable year, an employer contributes an amount which is less than the maximum deductible amount under section

111. Proposed Treas. Reg. $\$ \S 1.413-1(d), .413-2(c), 43$ Fed. Reg. 38,604-605 (1978).

112. I.R.C. $\$ 404(\mathrm{a})(\mathrm{l})(\mathrm{A})$. An employer may use any appropriate method for determining the limitation for a taxable year regardless of methods used in prior years. Treas. Reg. $\$ 1.404(a)-3(c)$, T.D. $7168,1972-1$ C.B. 118 (issued prior to ERISA).

113. The annual level cost of the plan is the aggregate of the annual amounts required to fund each participant's benefits over his expected service either as a level annual payment or as a level percentage of his compensation.

114. Treas. Reg. § 1.404(a)-7(a), T.D. 6534, 1961-1 C.B. 145. 
404(a)(1)(A), or 404(a)(2), it will not directly increase the inaximum deductible amount im future years, that is, there will be no deduction credit carryover. ${ }^{115}$

(c) Stock bonus and profit sharing plans. Section 404(a)(3)(A) permits an einployer to make aggregate deductible contributions under qualified stock bonus and profit sharing plans im any year in an anount equal to fifteen percent of participant coinpensation. If, im any taxable year, an employer contributes an amount im excess of fifteen percent of participant compensation, it will have an excess contribution carryforward. The excess contribution carryforward may be deducted in succeeding taxable years to the extent that contributions in such succeeding years are less than the inaximuin deductible amounts for such years. ${ }^{116}$ If the succeeding taxable year ends within a plan year during which the profit sharing or stock bonus trust is not exempt or if it ends after the trust has terminated, the excess contribution carryforward can be deducted in that year only to the extent of fifteen percent of the compensation of the current employees who were participants during the one-year period ending on the last day of the last month im which the trust was exempt. ${ }^{17}$

If, in any taxable year, an employer contributes an anount which is less than the maximum deductible amount, it will have a deduction credit carryover, and a larger deductible contribution may be made im a succeeding year; provided, that the total deductible contribution im any one year imcluding the deduction credit carryover cannot exceed twenty-five percent of the participants' compensation for that year. ${ }^{118}$

(d) Overlapping plans. If an employer maintains both a pension or annuity plan and a stock bonus or profit sharing plan and any employee is covered by both plans, then, in addition to the limitations on deductible contributions imposed on each plan, section 404(a)(7) prescribes an overall limitation on the aggregate contributions under the plans. The limitation for any taxable year is the greater of twentyfive percent of participants' compensation or the aunount necessary to satisfy the minimum funding standards under section 412 for the plan year ending within or with the taxable year (or any prior plan year).

If, im any taxable year, an employer contributes an aggregate

115. Rev. Rul. 70-30, 1970-1 C.B. 109. There may, of course, be an indirect effect, for example, through an mcrease in either the minimum funding requiremeut under section 412 or the annual level cost of the plan.

116. I.R.C. § 404(a)(3)(A); Treas. Reg. § 1.404(a)-9(a) (1961).

117. I.R.C. $\S 404(\mathrm{a})(3)(\mathrm{A})$; Treas. Reg. $\S 1.404(\mathrm{a})-9(\mathrm{~b})(2)(1961)$.

118. I.R.C. $\S 404(\mathrm{a})(3)(\mathrm{A})$. 
amount which is in excess of the naximum deductible amount under section 404(a)(7), it will have an excess contribution carryforward. The excess contribution carryforward inay be deducted in succeeding taxable years to the extent that aggregate contributions under the plans in such succeeding years are less than twenty-five percent of participants' coinpensation in such years. If the succeeding taxable year ends within a plan year during which any trust or any annuity plan is not exempt or if it ends after any trust or any annuity plan has terminated, then, for purposes of determining the compensation of participants in such trust or annuity plan, only those employees who were participants during the one year period ending on the last day of the last month in which the trust or annuity plan was exempt will be considered. ${ }^{119}$ The excess contribution carryforward under section 404(a)(7) is distinct froin, and in addition to, any excess contribution carryforward applicable to the individual trusts or annuity plans. ${ }^{120}$

If, in any taxable year, the aggregate contributions made by an employer are less than the maximum deductible amount permitted under section 404(a)(7), the maximum aggregate amount deductible in succeeding years is not directly increased, that is, there is no deduction credit carryover.

2. Section 381 Transactions. (a) Applicability. For qualified plan purposes, section 381(c)(11) requires the acquiring corporation in certain tax free reorganizations to be treated as if it were the transferor corporation. ${ }^{121}$ Section 381(c)(11) applies to a parent after the coinplete liquidation of a subsidiary, other than a liquidation which is treated under section 334(b)(2) as a purchase of assets, that is, a liquidation of a subsidiary whose stock was bought within two years of the liquidation. ${ }^{122}$ It also applies to the successor or acquiring corporation in certain tax free reorganizations as defined in section 368(a)(1), ${ }^{123}$ including: (i) an (A) reorganization (a statutory inerger or consolidation); (ii) a (C) reorganization (the acquisition of substantially all of the properties of another corporation solely for voting stock); (iii) a (D) reorganization meeting the requirements of sections 354(b)(1)(A) and 354(b)(1)(B) (the acquisition of substantially all of the assets of the transferor for stock of an acquiring corporation which after the acquisition is in control of, or under common control with, the transferor and

119. Treas. Reg. § 1.404(a)-13(a) (1961).

120. Treas. Reg. $\& 1.404(\mathrm{a})-13(\mathrm{c})$ (1956).

121. Treas. Reg. \& 1.381(c)(11)-1(b)(2) (1961).

I22. I.R.C. $\$ 381(\mathrm{a})(\mathrm{I})$.

123. I.R.C. $\S 381(\mathrm{a})(2)$. 
the distribution of such stock by the transferor); and (iv) an (F) reorganization (a mere change in identity, form or place of organization). ${ }^{124}$

(b) Contribution carryforward and deduction carryovers. The primcipal effect of section $381(\mathrm{c})(11)$ is to enable the acquiring corporation in a section 381 transaction to utilize the excess contribution carryforwards and deduction credit carryovers which would have been available to the transferor corporation under section 404 (even if the acquiring corporation employs none of the transferor's employees).

If a plan is terminated and not consolidated with, or replaced by, a comparable plan, the acquiring corporation's deductions are subject to the limitations incorporated in the regulations issued under section 404. ${ }^{125}$ Thus, the use of an excess contribution carryforward may be limited under a pension or annuity plan, and may be limited or lost entirely under a profit sharing or stock bonus plan; also, any deduction credit carryover under a profit sharing or stock bonus plan will be lost. ${ }^{126}$

Excess contribution carryforwards from different plans, from overlapping plans under section 404(a)(7), and from more than one predecessor corporation must each be kept separate and distinct. ${ }^{127}$

(c) Application of section 404(a)(6) to contributions by acquiring corporation. The taxable year of a transferor corporation im a section 381(c)(11) transaction ends on the date of transfer. ${ }^{128}$ If the acquiring corporation in a section 381 transaction makes a contribution to a plan on account of that year after the date of transfer, the question may arise as to whether the transferor corporation or the acquiring corporation is

124. I.R.C. \$368(a)(1). Pre-ERISA regulations provide that, if the acquiring corporation consolidates or replaces a plan with a comparable plan, the plan will not be treated as terminated. Treas. Reg. $\$ 1.381(c)(11)-1(d)(1)-(3)$ (1961). For this purpose, all qualified defined benefit pension plans, money purchase pension plans and annuity plans are considered comparable and all profit sharing and stock bonus plans are considered comparable regardless, in either case, of whether benefits or contributions have been curtailed or whether there has been a partial termination. Treas. Reg. $\$ 1.381$ (c)(11)-1(d)(4) (1961). Unless the regulations are changed, a plan that is terminated for purposes of Title IV of ERISA and section 411 of the Code (and presumably section 404 of the Code) might not be treated as terminated for purposes of section 381 , thus allowing the acquiring corporation to take advantage of carryovers and carryforwards not available to the transferor.

125. The transferor's deductions for prior contributions should not be adversely affected by the termination. Treas. Reg. $\$ 1.381$ (c)(11)-1(e) (1961); Rev. Rul. 58-406, 1958-2 C.B. 153. But cf. Rev. Rul. 69-25, 1969-1 C.B. 113 (abandonment of a plan for other than "business reasons" will be evidence that the plan was never bona fide).

126. See text accompanying notes 115,118 supra.

127. Treas. Reg. $\S 1.381(\mathrm{c})(11)-1(\mathrm{~h})$ (1972).

128. I.R.C. $\$ 381(\mathrm{~h})(1)$. 
entitled to the deduction. The transferor corporation will be entitled to claim the deduction if the contribution is made before the time prescribed in section 404(a)(6) for its short taxable year. ${ }^{129}$ If it is intended that the acquiring corporation obtain the deduction, it may be safest to delay the contribution until after the time prescribed in section 404(a)(6). However, in the absence of post-ERISA regulations under section 404(a)(6), an earher contribution should be deductible by the acquiring corporation unless either the deduction is actually claimed for the short year or the acquiring corporation designates the contribution as being on account of the short year in a writing to the plan administrator. ${ }^{130}$

(d) Contributions attributable to past-service benefits. Regulations under section 381 specifically provide that, for purposes of computing the cost of past-service credits under a plan, the acquiring corporation may include the cost for periods of service with the transferor ${ }^{131}$ and that contributions are deductible by the acquiring corporation even if the plan exclusively benefits former employees of the transferor. ${ }^{132}$

3. Non-Section 381 Transactions. (a) Generally. In an acquisition, divestiture, or other reorganization which is not a section 381 transaction, each corporation will, for qualified plan purposes, retain its tax attributes, including any qualified plan excess contribution carryforward or deduction credit carryover. The most important deduction issues for transferor corporations relate to the deductibility of further contributions on behalf of employees transferred to an acquiring corporation and the best utilization of any excess contribution carryforward or deduction credit carryovers. The most important deduction issue for a successor or acquiring corporation relates to the funding of benefits for service accrued with a transferor.

(b) Transferor corporation. If a transferor corporation inaintains a defined benefit pension plan, then, assuming that it remains qualified, ${ }^{133}$ the transferor will be able to deduct contributions made to continue funding benefits of its former employees who were transferred to

129. Treas. Reg. $\S 1.381(c)(11)-1(b)(2)$ (1972).

130. Rev. Rul. 76-28, 1976-1 C.B. 106.

131. Treas. Reg. $\S 1.381(\mathrm{c})(11)-1(\mathrm{~g})(1972)$.

132. Treas. Reg. $\S 1.381$ (c)(11)-1(b)(2) (1972). Note that section 381(c)(16) dealing with deductions for payments on a predecessor's obligations if the obligation is not reflected in the purchase price does not supersede section 381(c)(11). Accordingly, contributions ought to be deductible under section 381(c)(11) even if reflected in the purchase price.

133. See text accompanying notes 49-51 supra (relating to the potential disqualification of a transferor's plan by reason of discrimination). 
the successor or acquiring corporation. ${ }^{134}$ If a transferor corporation which is to be liquidated or merged out of existence maintams a stock bonus or profit sharing plan with a discretionary contribution formula and a contribution is desired for its short year, care must be taken to assure that the necessary corporate steps to authorize a contribution are taken prior to the liquidation or merger. ${ }^{135}$ If a transferor has any excess contribution carryforward, it will, of course, want to obtaim the maximum utilization of the carryforward at the earhest possible time. In the case of a transferor corporation which is to be liquidated, immediate utilization is required to avoid the loss of the carryforward.

In the case of a pension plan mamtamed by a transferor corporation, substantial numbers of whose employees are being transferred or otherwise terminated, it may be possible to obtaim the maximun utilization of an excess contribution carryforward by determining the maximum deductible amount under section 404(a)(1)(A)(ii) (the annual level cost of the plan over the participant's expected service). If all employees are to be transferred or otherwise terminated, there would be no further expected service and the full amount of any carryforward (up to the full funding limitation) ought to be deductible in the year of the transfers or terminations. If the pension plan is to be terminated, Treasury Regulations $\S 1.404(a)-7(b)$ appears to prevent a full deduction of the carryover. That regulation provides that, if an employer's taxable year ends after the termination of a trust or within a nonexeinpt taxable year of the trust, any excess contribution carryforward may be deducted for that year only to the extent permitted by the predecessor of section 404(a)(1)(A)(iii) (normal cost plus amortization of past-service cost over ten years). ${ }^{136}$ Assuming the regulation to be valid postERISA, the transferor may nevertheless avoid its impact if the trust is not terminated and does not lose its exempt status prior to the last day of the transferor's taxable year. Because an exempt trust must form a part of a qualified plan, the transferor should consider continuing the plan and making a contribution to the trust on the last day of its taxable year to assure that neither the plan nor the trust is considered termi-

134. As a minimum, the amount necessary to meet the minimum funding requirements of section 412 would be deductible under section 404(a)(1)(A)(i). See also Rev. Rul. 70-316, 1970-1 C.B. 91 .

135. Under the terms of most plans, a resolution by the board of directors is required. Note, however, the statement of Isidore Goodinan, former Chief, IRS Pension Trust Branch, in a speech delivered October 8,1971 , that if a contract obligates the acquiring corporation to make a contribution on behalf of the seller, the seller obtains a deduction. [1971] PENS. PLAN GUIDE (CCH) I] 3610 .

136. See note 114 supra and accompanying text. 
nated prior to that day. ${ }^{137}$

In general, if the transferor maintains a stock bonus or profit sharing plan and all employees covered by the plan are to be transferred to the acquiring corporation or otherwise terminated, any excess contribution carryforward or deduction credit carryover will be lost. However, if the transferor inaintains or intends to adopt other stock bonus or profit sharing plans for other employees, it would appear that the contribution carryforwards and deduction carryovers could be utilized for such purposes by extending the coverage of the plan to such other einployees prior to the transaction.

(c) Acquiring corporation. If the acquiring corporation assumes a defined benefit pension plan of the transferor or accrues benefits under its own defined benefit pension plan for service performed for the transferor corporation, two issues arise with respect to the deduction of the contributions attributable to such service. The first issue is whether such contributions will result in unreasonable compensation being paid to the transferred employees. The second issue is whether such contributions inay be considered part of the purchase price and therefore nondeductible.

Revenue Ruling 62-139138 sets forth the general principles applicable to the crediting of service with former employers for purposes of benefit accrual under a defined benefit pension plan. The ruling states that, regardless of the degree of affiliation between the existing einployer and the former employer, service with the former employer may be credited if all einployees of the former employer are treated uniformly, if credit for such service does not result in discrimination in favor of the prohibited group, that is, officers, shareholders and highly compensated employees, and if the crediting does not result in the duplication of benefits. ${ }^{139}$ A stateinent in the ruling that the allowance for service with the former enployer is not deened compensation for that service but is considered a unit of ineasurement of the reasonableness of the current coinpensation for services rendered to the present enployer, ${ }^{140}$ raises a question, in the case of the assumption of the transferor's pension plan by the acquiring corporation, as to whether any contributions inade on behalf of terminated or retired employees of the transferor corporation are deductible since they provide no service for

137. For a more detailed discussion of this issue, see Musto, Carryover Problems of Compensation Plans in Corporate Reorganizations, 25 J. TAX. 270 (1966).

138. 1962-2 C.B. 123.

139. Id.

140. Id. 
the acquiring corporation. Similar questions may arise with respect to the deductibility of contributions, either to a new plan or to a plan assumed by the acquiring corporation, to fund past service benefits of employees who will be with the acquiring corporation for only a short period. Notably, however, Revenue Ruling 62-139 approached the crediting of service with a participant's former employer without regard to whether that einployer was a predecessor of the employer maintaining the plan. Other rulings dealing only with service with a predecessor of the employer maintaining the plan do not condition their holdings on the reasonableness of the contributions as compensation for service with the successor corporation. ${ }^{141}$

When a corporation purchases a busmess in a non-section 381 transaction and obligates itself to continue one or more pension plans maintained by the transferor, a question arises as to whether contributions to fund benefits accrued for service with the transferor are deductible under section 404 or are instead to be treated as a portion of the purchase price.

Generally, habilities assumed by an acquiring corporation, including a parent in a section 334(b)(2) hquidation, are treated as part of the purchase price of the assets acquired and are allocated among the assets. These liabilities are allocated even if they would have been deductible by the seller and even if they are remote contingent obligations at the time of the purchase which do not mature into accrued legal liabilities until after the purchase date. ${ }^{142}$ Nevertheless, contributions to fund pension benefits attributable to the transferor corporation should be deductible under section 404. In many cases the employer has no true obligation to continue to fund a plan, ${ }^{143}$ that is, it may unilaterally terminate a plan, subject, of course, to possible liability to the PBGC. Even if pension plan contributions are viewed as liabilities of an employer, they ought to be deductible by an acquiring corporation since section 404 provides a special rule for deducting plan contributions and imposes no limitation with respect to contributions made pursuant to a contractual obligation.

141. Rev. Rul. 58-165, 1958-1 C.B. 209; Private Letter Ruling 7816063, 1978 Fed. Taxes Private Letter Rulings (P-H) I 1194; Private Letter Ruling 7735003, 1977 Fed. Taxes Private Letter Rulings (P-H) I] 1086. See also Special Ruling, Oct. 23, 1944, [1944] Pens. PLan Guide (CCH) I] 17,302 .

142. See, e.g., Pacific Transport Co. v. Commissioner, 483 F.2d 209 (9th Cir. 1973), cert. denied, 415 U.S. 948 (1974); W.D. Haden Co. v. Commissioner, 165 F.2d 588 (5th Cir. 1948); Holdcraft Transp. Co. v. Commissioner, 153 F.2d 323 (8th Cir. 1946); Leavitt v. Commissioner, 41 T.C.M. (P-H) 474 (1972).

143. The employer is of course subject to the requirements of section 412 and any applicable union contracts. 
The holding in $F \& D$ Rentals, Inc. v. Commissioner ${ }^{144}$ supports the position that contributions to a pension plan should be governed by section 404 even where a purchaser has obhigated itself to fund the plan. In that case, the court disallowed a deduction for anounts which a purchaser of assets was obligated to contribute to a pension plan under the purchase agreenent but which it failed to contribute within the time provided by section 404 . The court also rejected the taxpayer's theory that the amount of the contributions should be added to the cost basis of the purchased assets:

Since the Code treats pension plan contributions as a deduction, we are not persuaded by the arguinent that petitioner should be allowed to increase the cost basis of the assets it acquired from South Bend No. 1 by adding its unpaid pension plan obhigations. Contingent obligations unsusceptible to present valuation, which are assumed as part of a purchase agreement, are not to be included in the cost basis of assets. ${ }^{45}$

Furtlier support is found in a 1978 private letter ruling which held that in a 334(b)(2) liquidation which is treated as a purchase of assets by the parent corporation, the deductibility of pension contributions of the parent after the liquidation will be governed by section 404 , and such contributions will not be treated as part of the cost of the subsidiary's assets. ${ }^{146}$

\section{REPORTING AND Disclosure REQUIREMENTS}

The following reporting and disclosure requiresnents relating to qualified plans nay be affected by a Corporate Transaction. ${ }^{147}$

\section{A. Reports To Be Filed With the IRS.}

1. Annual Return. Section 6058(a) of the Code requires the plan administrator ${ }^{148}$ of each qualified plan to file an annual return. The annual return should be filed on a series 5500 form (Annual Return/Report Form of Einployee Benefit Plan). The due date for any plan year is the last day of the seventh month following the close of the year; however, extensions may be requested on Form 5558 and, in the case of a single-employer plan with a plan year coincident with the einployer's taxable year, the due date will automatically be extended if

144. 365 F.2d 34 (7th Cir. 1966).

145. Id.

146. Private Letter Ruling 7816063, 1978 Fed. Taxes Private Letter Rulings (P-H) II 1194.

147. Reporting and disclosure requirements unlikely to be affected by a Corporate Transaction are not listed.

148. For purposes of subpart VII A of this Article, "plan administrator" means a plan administrator as defined in section $414(\mathrm{~g})$ of the Code. 
the employer has been granted an extension to file its tax return. ${ }^{149}$

If a plan is frozen or terminated, annual returns must be filed until all assets are distributed. The plan year ends upon the merger or consolidation of a plan or upon the complete distribution of plan assets, and, accordimgly, unless an extension is obtamed, an annual return must be filed by the last day of the seventh month following the close of that short year.

2. Annual Registration Statement. Section 6057(a) of the Code requires the plan administrator of each qualified plan to file an annual registration statement providing information relatimg to plan participants who have separated from service and who are eligible for a deferred vested benefit. Such a statement is required to be filed even with respect to participants who might be covered by a replacement plan. ${ }^{150}$

3. Change in Status. Section 6057(b) of the Code requires a plan administrator to file a notification of a change in status if the name of the plan administrator is changed, the plan is terminated, the plan is merged or consolidated with another plan, or the plan is divided imto two or more plans. Treasury Regulations $\S 301.6057-2$ provides that the notification of change im status must be filed on the annual return for the plan year in which the cliange in status occurred; however, the 1977 instructions for Form 5500 provide in paragraph $\mathrm{K}$ of the general instructions that the filing of Form 5310 (discussed below) satisfies the notification requireinent with respect to a plan merger or consolidation or a plan division.

4. Valuation Statement on Plan Merger or Transfer of Assets or Liabilities. Section 6058(b) of the Code requires that, at least thirty days prior to a plan inerger or consolidation or a transfer of plan assets or liabilities, the plan administrator file an actuarial statement evidencing comphance with the requirements of section 401(a)(12). Form 5310 is to be used for this purpose.

5. Change in Plan Years. Section 412(c)(5) of the Code provides that a change in the plan year of a defined benefit pension plan, annuity plan or money purchase pension plan requires approval of the Secretary of the Treasury. Section 412 does not apply to profit sharing or stock bonus plans. Form 1128 is to be used for requesting the approval.

149. 1977 Instructions for Form 5500, General Instructions paragraph B.

150. Treas. Reg. \& 301.6057-1(a)(4) (1978) requires the statement to be filed on Schedule SSA as an attachment to the annual return. 
6. Application for Determination Letter. In most cases an employer will want to seek a determination letter that each affected plan continues to qualify after the Corporate Transaction. Among the changes resultimg from a Corporate Transaction that would prompt an employer to request such a determination are the changed employee data affecting compliance with the minimum coverage requirenents under section 410 , amendments to plans to cause uniformity among the various plans maintained after the Corporate Transaction, amendments to plans to credit service with a predecessor employer, and freezing or termination of a plan. A determination letter should be requested by filing the applicable IRS series 5300 form with the appropriate district director.

B. Reports To Be Filed with the Department of Labor.

1. Annual Report. Section 101(b)(4) of ERISA requires that a plan administrator ${ }^{151}$ file an annual report with the Secretary of Labor. A Department of Labor regulation requires the annual report to be filed on a series 5500 form. ${ }^{152}$ The annual return filed with the IRS and discussed in paragraph $\mathrm{Al}$ above fulfills this requirement.

2. Description of Plan and Material Modifications. Sections 101(b)(2) and (3) of ERISA require a plan administrator to file a plan description and a description of material modifications to a plan with the Secretary of Labor. Although the plan description is presently filed on form EBS-1, the Department of Labor plans to eliminate that form. Under a Department of Labor regulation the requirement to file a description of material modifications is fulfilled by filing with the Department a copy of the summary description of the modification distributed to participants. ${ }^{153}$

3. Terminal and Supplementary Reports. Pursuant to section 101(c) of ERISA, the Secretary of Labor may require a terminal or supplementary report to be filed by a plan administrator of a plan which is winding up its affairs or is terminated. ${ }^{154}$

\section{Reports To Be Filed with the PBGC.}

The following reports apply only to defined benefit pension plans:

151. For purposes of subparts VII B and VII C, "plan administrator" means an administrator as defined in section $3(16)$ (A) of ERISA.

152. 29 C.F.R. \& 2520.103-1(b) (1978).

153. 29 C.F.R. $\$ 2520.104-4(b)(1)$ (1978).

154. 29 C.F.R. $\$ 2606.3$ (1978). 
1. Annual Reports. Section 4065 of ERISA requires that a plan administrator file an annual report with the PBGC which includes a stateinent of any reportable events occurring during the year. A PBGC regulation requires the report to be filed on a series 5500 form.

2. Notice of Plan Termination. Section 4041(a) of ERISA requires a plan administrator to file a notice with the PBGC at least ten days prior to the date as of which a plan terminates. PBGC regulations set forth the requirements of such a notice with respect to non-inultieinployer plans. ${ }^{155}$

3. Notice of Reportable Events. Section 4043(a) of ERISA requires a plan administrator to notify the PBGC of a reportable event within thirty days of its occurrence. Reportable events are defined in section 4043(b) and include any amendinent of a plan if, after the amendinent, any participant will ultinnately receive a smaller benefit than he would have received if the plan had not been amended: for exainple, an amendinent reducing the rate of future accruals or eliminating life insurance coverage, ${ }^{156}$ a reduction in the number of active participants by twenty percent in one year or by twenty-five percent in two years; the termination or partial termination of a plan; and a plan merger or consolidation or transfer of plan assets or liabilities.

The PBGC has proposed regulations to waive the thirty-day notice requirements for certain reportable events and include as additional reportable events bankruptcy or insolvency proceedings against the corporation maintaining the plan or against any corporation under coininon control with it, the coinunencement of a liquidation or dissolution of the corporation inaintaining the plan or of any corporation under common control with it, and a change of plan sponsor or a change in ownership of the plan sponsor such that the plan sponsor is no longer a nember of the same controlled group. ${ }^{157}$

4. Notice of Facility Shutdown or Withdrawal by Substantial Employer. Under sections 4062(e) and 4063(a) of ERISA, a plan administrator inust notify the PBGC within sixty days of the cessation of operations at a facility which results in the separation from service of more then twenty percent of the plan participants or the withdrawal of a substantial employer from a plan to which inore than one einployer

155. 29 C.F.R. $\$ \$ 2604.1-6$ (1978).

156. PBGC Opinion Letters 76-114 (Oct. 1, 1976); 76-53 (Apr. 15, 1976).

157. Proposed PBGC Regulations 29 C.F.R. $\$ 2617$, 42 Fed. Reg. 59285-94 (1977) (to be codified in 29 C.F.R. $\$ \$ 2617.1-.19$ ). 
contributes. ${ }^{158}$

\section{Disclosures to Participants.}

1. Description of Material Modification of Plan. A plan administrator must furnish each participant with a summary description of any material modification of a plan not later than 210 days after the close of the plan year in which the modification was adopted. ${ }^{159}$

2. Statement of Deferred Vested Benefits. A plan administrator must provide a stateinent of deferred benefits to each participant whose deferred vested benefit is reported on the annual registration stateinent. $^{160}$

\section{Miscellaneous Considerations}

\section{A. Review of Documents and Funding.}

Plan documents should be reviewed prior to the closing of a Corporate Transaction to determine what restrictions, if any, are placed on the sponsor's ability to annend or terminate a plan or on a successor's ability to contimue a plan. Such restrictions may need to be amended prior to a Corporate Transaction to accoinphish the parties' goals. Other amendments may also be necessary or desirable. For example, if a profit sharing plan is to be mamtamed for the benefit of a division, then, in addition to any limitation imposed in terms of the division's profitability, contributions must be limited to current and accumulated profits of the corporation. If inore than one plan is to be mamtamed by an employer or controlled group after a Corporate Transaction, plan documents may need amendments to facilitate intra-company (or intragroup) transfers.

In addition to the plan documents, umion contracts, prior disclosures to participants and funding contracts should all be reviewed in advance to determine what restrictions, if any, such documents place on the ability of the parties to a Corporate Transaction to negotiate with respect to their plans. Union contracts often provide that a pension plan will not be terminated prior to the expiration of the contract and that a terminated employee will continue to accrue service after his termination. For example, a terminated employee may contimue to accrue service as long as he continues to accrue semority. Such a combination could cause substantial imcreases in hability even after all

158. See notes 26-27 supra and accompanying text.

159. Department of Labor Regulation, 29 C.F.R. § 2520.104b-3(1978).

160. See text accompanying note 150 supra. 
participants in a plan have been terminated. If a plan is terminated without sufficient assets to pay all benefits, union contracts and prior disclosures to participants nuay give rise to hitation by enuployees asserting a contractual right to their full pensions. ${ }^{161}$ Investment contracts issued by insurance coinpanies often require that plan amendinents affecting the obligations of the insurer must be approved by the imsurer in advance and often impose significant penalties if all or a portion of a plan's assets are withdrawn front the contract before its expiration.

Before negotiations are concluded, an acquiring corporation ouglit to lave its actuary review the actuarial assumptions underlying an acquired corporation's reported defined benefit pension plan expenses. What inay appear to be minor variances in assumptions can result in significant clianges in current pension expenses. One rule of thumb is that an increase of one-lialf percent in a plan's interest assumption will reduce current funding requirements by ten percent. ${ }^{162}$ Funding valuations slould also be reviewed to determine if they were prepared on the assunption that the plan would be terminated or on the assumption that the plan would continue. Similarly, an actuary should review the actuarial reports of each of the acquired corporation's defined benefit pension plans (including inultieinployer plans to which it contributes) to determine the potential liability that could be mcurred under Title IV of ERISA if the plans should terminate. What may appear to a lay person to be a fully funded plan may in fact lave significant unfunded benefits. For exaniple, depending on the actuarial inethod used, a significant liability could be incurred under Title IV even if a plan has no "unfunded accrued liability." 163

\section{B. Prohibited Transaction Potential.}

If plan assets include einployer securities or employer property, the structure of a Corporate Transaction must be reviewed carefully to assure that it does not result in a prohibited transaction (as described in section 406 of ERISA and section 4975 of the Code). Of course, any action taken by plan trustees with respect to sucli assets is also subject to the fiduciary standards imposed by ERISA.

A prohibited transaction nuay result, for example, where an ac-

161. See, e.g., Hoefel v. Atlas Tack Corp., 581 F.2d 1 (1st Cir. 1978), cert. denied, 99 S. Ct. 1227 (1979); Hurd v. Hutnik, 419 F. Supp. 630 (D.N.J. 1976); In re Alan Wood Steel Co., 212 Pens. Rep. (BNA) D-1 (E.D. Pa., Bankruptcy No. 77-930, Oct. 13, 1978).

162. A 1975 Twentieth Century Fund Report, Conficts of Interest: Corporate Pension Fund Asset Management, noted a $\$ 42$ million reduction in U.S. Steel's annual pension costs when it raised its interest assumption from five percent to six percent in 1971.

163. 29 U.S.C. $\S 1002(30)(1976)$. 
quiring corporation is, prior to the acquisition, a party in interest or disqualified person (as defined in section 3(14) of ERISA and section 4975(e) of the Code, respectively) with respect to a plan. A prohibited transaction could also occur where a trustee, as a principal shareholder of an acquired corporation, warrants certain inatters, if, on breach of any such warranty, a portion of the purchase price received by such trustee inust be returned to the acquiring corporation.

\section{Section 415 Problems.}

The limitations on benefits and contributions imposed by section 415 of the Code may be affected by a Corporate Transaction in a number of ways.

1. Limitation Year. Section 415 limitations are apphed on the basis of "limitation years" selected by the employer or plan administrator. ${ }^{164}$ Because the failure to elect a limitation year coincident with a plan year could easily cause a defined contribution plan to exceed the section 415 limits, the foregoing requirement may cause a problem if a Corporate Transaction results in a controlled group of corporations maintaining defined contribution plans with different plan years, unless appropriate corporate resolutions electing separate limitation years are adopted prior to the transaction.

2. Years of Service for Defined Benefit Plan Limitation. Section 415(b)(5) provides that, if an employee has less than ten years of service, the limitation otherwise imposed by section 415(b) on the benefit payable on his behalf is reduced proportionately. Revenue Ruling 75481 provides that years of service for this purpose will be determined under section 411(a)(5) of the Code. ${ }^{165}$ Unless required to be credited under section 414(a) of the Code, service with a predecessor employer

164. Rev. Rul. 75-481, § 2.01(1), 1975-2 C.B. 188, 189.

Except for elections made prior to December 31, 1979, an election of a limitation year cannot be made retroactively. Rev. Rul. 75-481, 1975-2 C.B. 188, 189; Rev. Rul. 79-5, \& 3, 1979-1 I.R.B. 12,13 . The problem if a limitation year is not coincident with a plan year is illustrated by the following example: Assume that $A$ corporation maintains a profit sharing plan on a plan year of April 1 through March 31, and that it makes a contribution as of March 31, 1980, equal to $10 \%$ of the participants' compensation for that plan year. Assume further that employce $X$ earns $\$ 1,000$ per month and receives a contribution of $\$ 1,200$ allocated to his account as of March 31, 1980. If employee $X$ terminates on April 1, 1980, his compensation for the calendar year 1980 would be $\$ 3,000$. If the calendar year is also the limitation year, the annual addition for $1980(\$ 1,200)$ would be well im excess of $25 \%$ of his coinpensation for 1979 (\$750). Similar problems arise if an employee is covered by two or more defined contribution plans with different limitation years. See Rev. Rul. 79-5, § 8, 1979-1 I.R.B. 12, 14.

165. Rev. Rul. $75-481, \S 3.04,1975-2$ C.B. $188,191$. 
is not required to be credited for section 411 purposes and, therefore, under the ruling such service would not be includible for purposes of the section $415(b)(5)$ reduction.

3. Years of Service for Defined Contribution Fraction. Finally, the defined contribution plan fraction set forth in section 415(e)(3) of the Code for purposes of determining the overall limitation applicable to a participant who is covered both by a defined benefit plan and by a defined contribution plan inaintained by the same employer (or controlled group) is based upon the participant's "year[s] of service with the employer." 166 As of this writing, however, there are no regulations or published rulings setting forth the extent to which service with a predecessor employer may be utilized in determining a participant's defined contribution plan fraction.

\section{CONClUSion}

ERISA increased the necessity for careful advance consideration of the effects which a Corporate Transaction inay have on the qualified retirement plans mamtamed by the parties to the transaction.

This Article has dealt with two basic categories of effects. The first category imcludes the direct effects which a Corporate Transaction may have on the costs associated with the parties' retirement plans. The area of concern here which has received the inost attention post-ERISA is the potential liability which a party to a Corporate Transaction may incur, either immediately or at a later date, by reason of the application of Title IV of ERISA to defined benefit pension plans. An assessinent of that liability may require a review of the actuarial reports prepared with respect to all of the defined benefit pension plans (including multieinployer plans) to which the parties contribute. A review of the actuarial reports and underlying assumptions may also be necessary to determine whether a party's reported pension expenses are appropriate for the level of benefits provided by its plans and, therefore, accurately reflect the costs of the plans. Contribution carryforwards and deduction carryovers for all plans should also be reviewed to assure that the parties do not imadvertently lose their ability to deduct contributions.

The second category of effects of a Corporate Transaction are those which affect the qualified status of a plan and, indirectly, the costs of inaintaining the plan. The two principal effects in this category are the effect which the transaction may have on the application of the minimum coverage requirements of section 410 of the Code and the

166. I.R.C. $\S 415(e)(3)$. 
minimum vesting requirements of section 411 of the Code.

In addition to the considerations discussed in this Article, a party to a Corporate Transaction will, of course, want to review the alternatives available with respect to its plans in terms of the compatibility of the alternatives with its general philosophy regarding types and levels of employee benefits and in terms of the tax consequences of the alternatives to its employees. 
